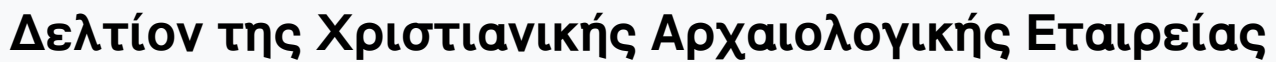

Tó 36 (2015)

$\Delta \varepsilon \lambda$ Tíov XAE 36 (2015), Пعрі́oঠos $\Delta^{\prime}$

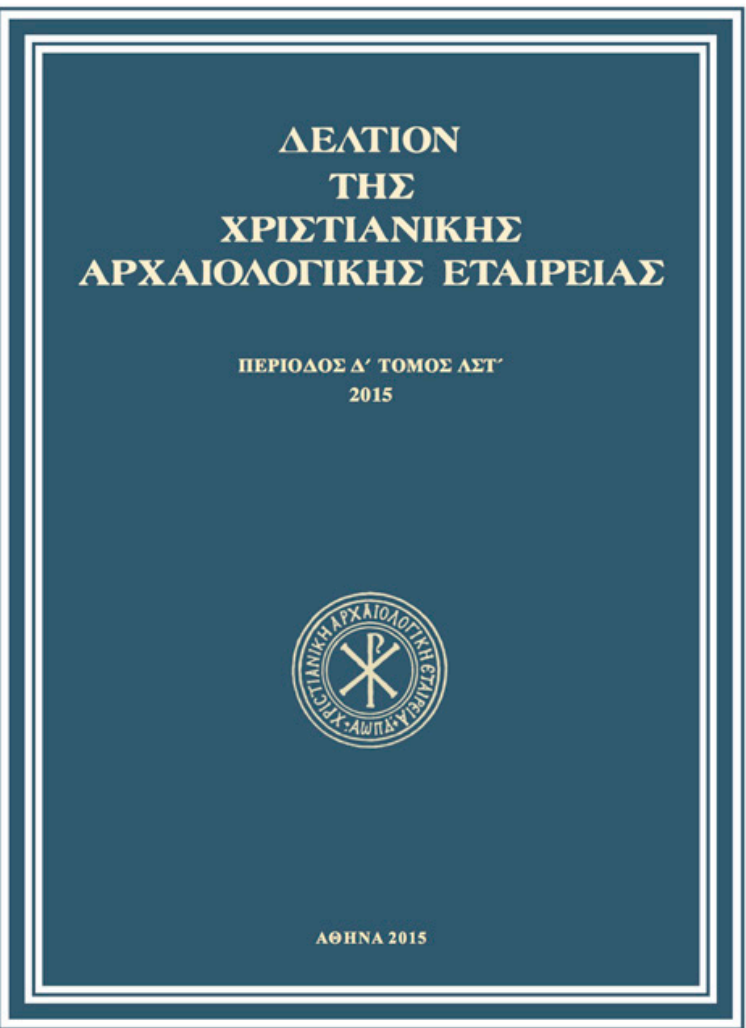

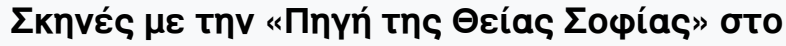

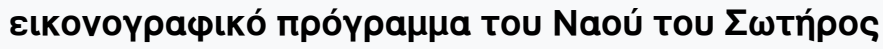

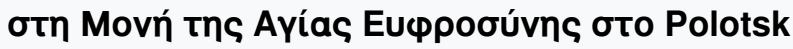

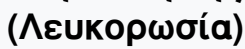

†Vladimir D. SARABIANOV

doi: $\underline{10.12681 / \text { dchae. } 1773}$

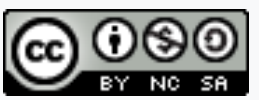

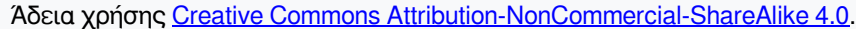

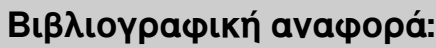

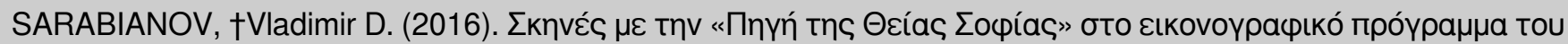

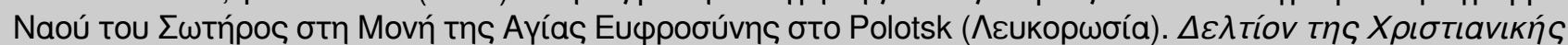
Архаıолоүıки́s Eтаıрві́as, 36, 49-64. https://doi.org/10.12681/dchae.1773 


\section{SCENES OF THE "SOURCES OF DIVINE WISDOM" WITHIN THE ICONOGRAPHICAL PROGRAM OF THE CHURCH OF THE SAVIOR IN THE MONASTERY OF EUPHROSYNIA, POLOTSK (BELARUS)}

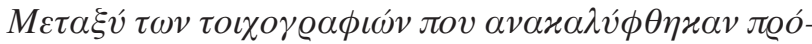

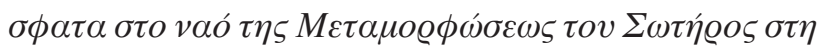

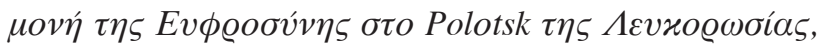

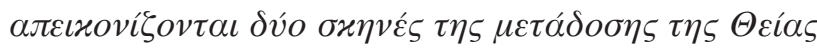

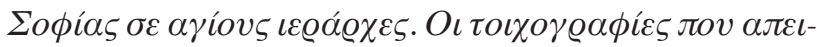

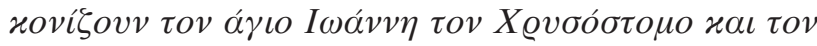

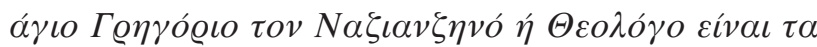

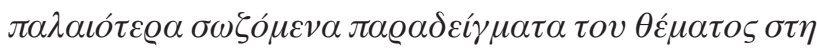

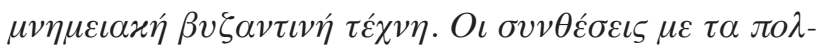

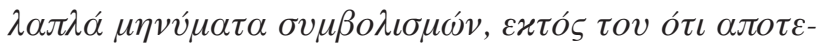

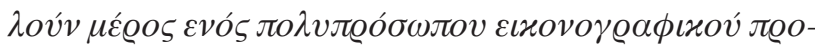

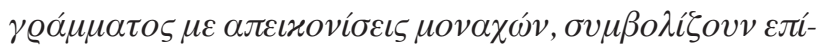

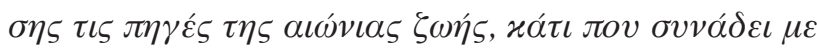

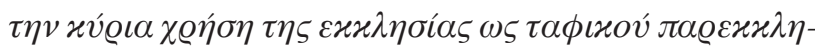

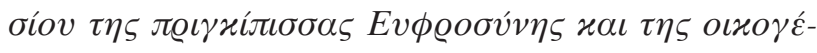

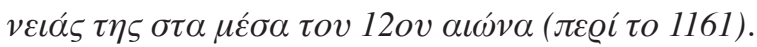

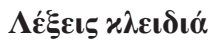

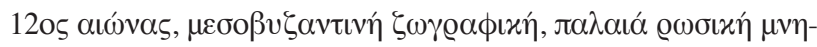

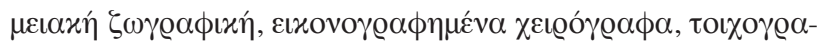

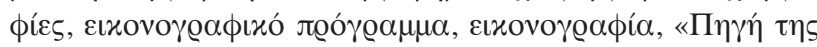

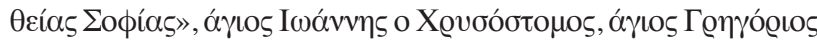

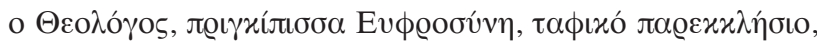

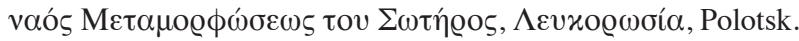

he murals of the Transfiguration church in the monastery of Euphrosynia in Polotsk, built and decorated ca. 1161 by Saint Euphrosynia of Polotsk, include a number of rare scenes with elaborate iconography, thematic variety, and profound theological interpretation. Of special interest are two scenes of "The Sources of Divine Wisdom" in the fully visible lower zone of the south and north walls of the dome cross. That on the south wall is dedicated to Saint John Chrysostom and that on the wall opposite to Saint Gregory the Theologian. Both their location in the lower zone and their unusual subject show the special role of these compositions in the overall program of the Savior's church decoration.
Two recently-recovered frescoes in the Transfiguration church of the monastery of Euphrosynia in Polotsk, Belarus, depict scenes of transition of Divine Wisdom to bishop Saints. These frescoes, which feature Saint John Chrysostom and Saint Gregory of Nazianzos or the Theologian, represent the earliest surviving examples of the inclusion of this theme in church fresco decoration. The compositions possess multiple layers of meaning: besides being part of the multi-figure program depicting monks, they symbolize the sources of eternal life - something perfectly in tune with the main function of the church as the burial chapel of the princess Euphrosynia and her family during the mid-12th century (ca. 1161).

\section{Keywords}

12th century, Middle-Byzantine painting, Old Russian monumental painting, mural paintings, miniatures, iconographic program, iconography, "Sources of Divine Wisdom," Saint John Chrysostom, Saint Gregory of Nazianzos or the Theologian, princess Euphrosynia, burial church, Transfiguration church in Euphrosynia's monastery, Belarus, Polotsk.

The structure of the Savior's church decoration is strictly symmetric, and only singular or secondary cases comprise exceptions. The decoration on the south and the north walls of the cross arms is based on a principle of double scenes, dual in terms of content and composition. The lunettes are occupied by two monumental scenes, the Crucifixion and the Ascension; below these are the Entry to Jerusalem and the Resurrection of Lazarus, while the middle zone of the north wall carries a huge composition of the Dormition, opposed on the south by the Nativity in a version with elaborately-detailed

\footnotetext{
* State Institute of Art History, Moscow,vdsar@mail.ru
} 


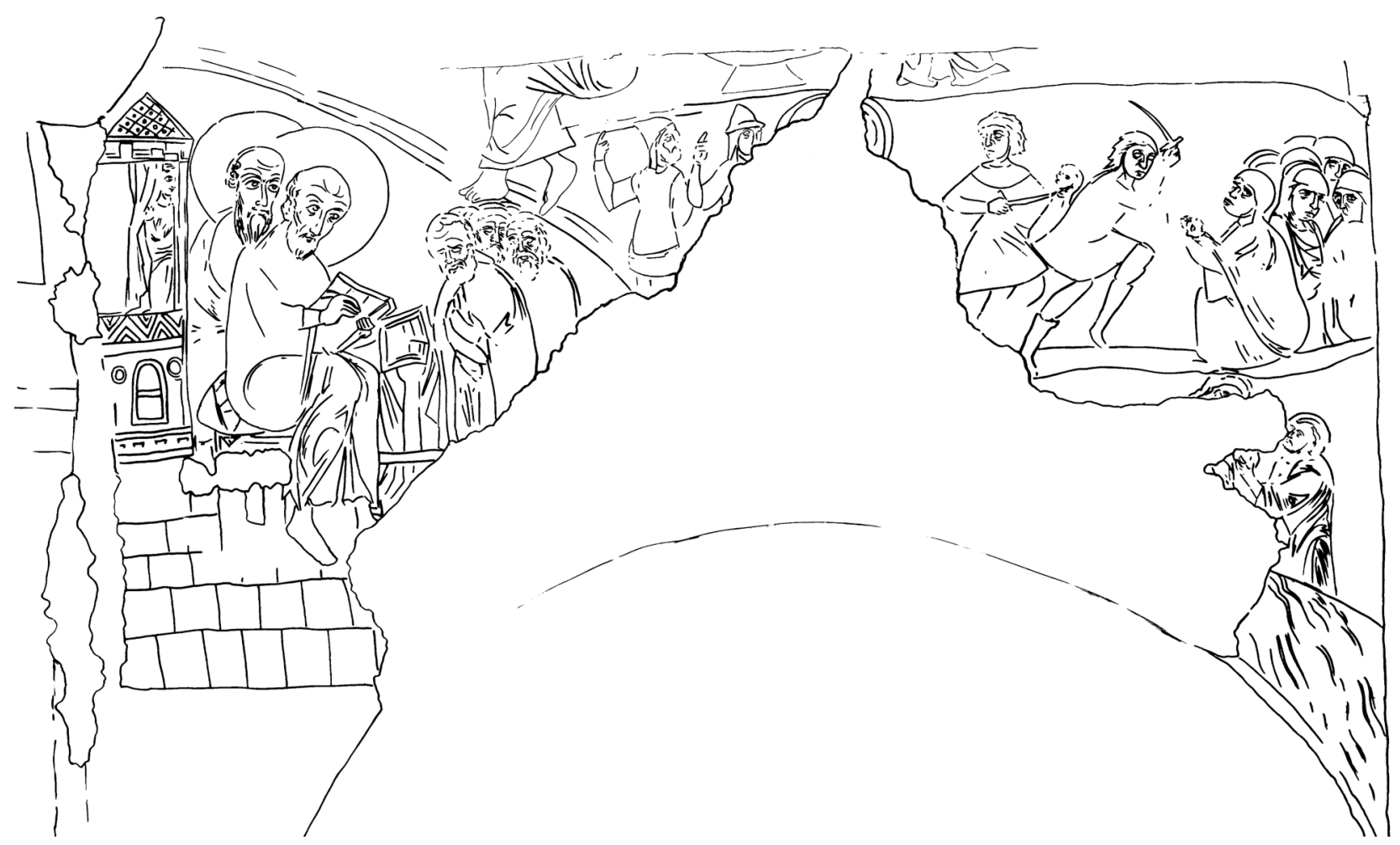

Fig. 1. Polotsk, monastery of Euphrosyna, church of the Savior. The "Source of Divine Wisdom" of Saint John Chrysostom. Drawing.

iconography. The scenes in the middle zone extend to the side apses or rather, extend outward from the prothesis and the diaconicon into the naos, covering the whole width of the facing walls of the cross arms. Thus, the side apses and the main space are unified by the expansion of the Evangelistic scenes.

The entire lower zone is given over to the scenes of interest to us here, which like the Evangelistic scenes occupy the entire width of the wall. These compositions do not extend to the side apses, because originally there was a wooden altar screen at their level which can be quite accurately reconstructed from the remaining elements and traces of construction. At the same time, the compositions of the Bishops' Sources of Divine Wisdom are not divided from the Dormition and the Nativity above, but unified in one scenic space. The Sources of Wisdom scenes are composed in a peculiar way, since they originally framed two arcosolia which occupied the entire width of the northern and the southern walls. These arcosolium niches were probably seen as the future burial places of the church's founder, the abbess Euphrosynia and her younger sister, who succeeded her as the monastery superior. ${ }^{1}$ Both scenes are situated so as to frame the arcoso- lia, rising a little above them, and thus the main action here is in the corner parts of the scenes on the sides of the arcosolia vaults. Today these arcosolia are not entirely visible, since the south one was hewed down to make a door during a later rebuilding, and the north one was blocked up completely. This also explains the loss of the central parts of the scenes. However, due to the unusual form of composition, these did not contain any significant images.

The south wall carries the composition the "Source of Divine Wisdom" of Saint John Chrysostom (Figs 1,2), which is based on the bishop's vita. The bishop himself is presented in monk's garments in the left part of the scene on the pier between the arcosolium vault and the joining of the altar screen. He sits at a desk writing in an open book, as the Apostle Peter

\footnotetext{
${ }^{1}$ For the burial character of the iconographic program of the Savior's church see V. Sarabianov, "The Church-reliquary of St. Eyphrosynia of Polotsk. To the Reconstruction of the Original Idea of the Savior's Church of Euphrosynia's Monastery," The Image of Byzantium, Papers in Honor of O. S. Popova, Moscow 2008, 427-456 (in Russian with English summary).
} 


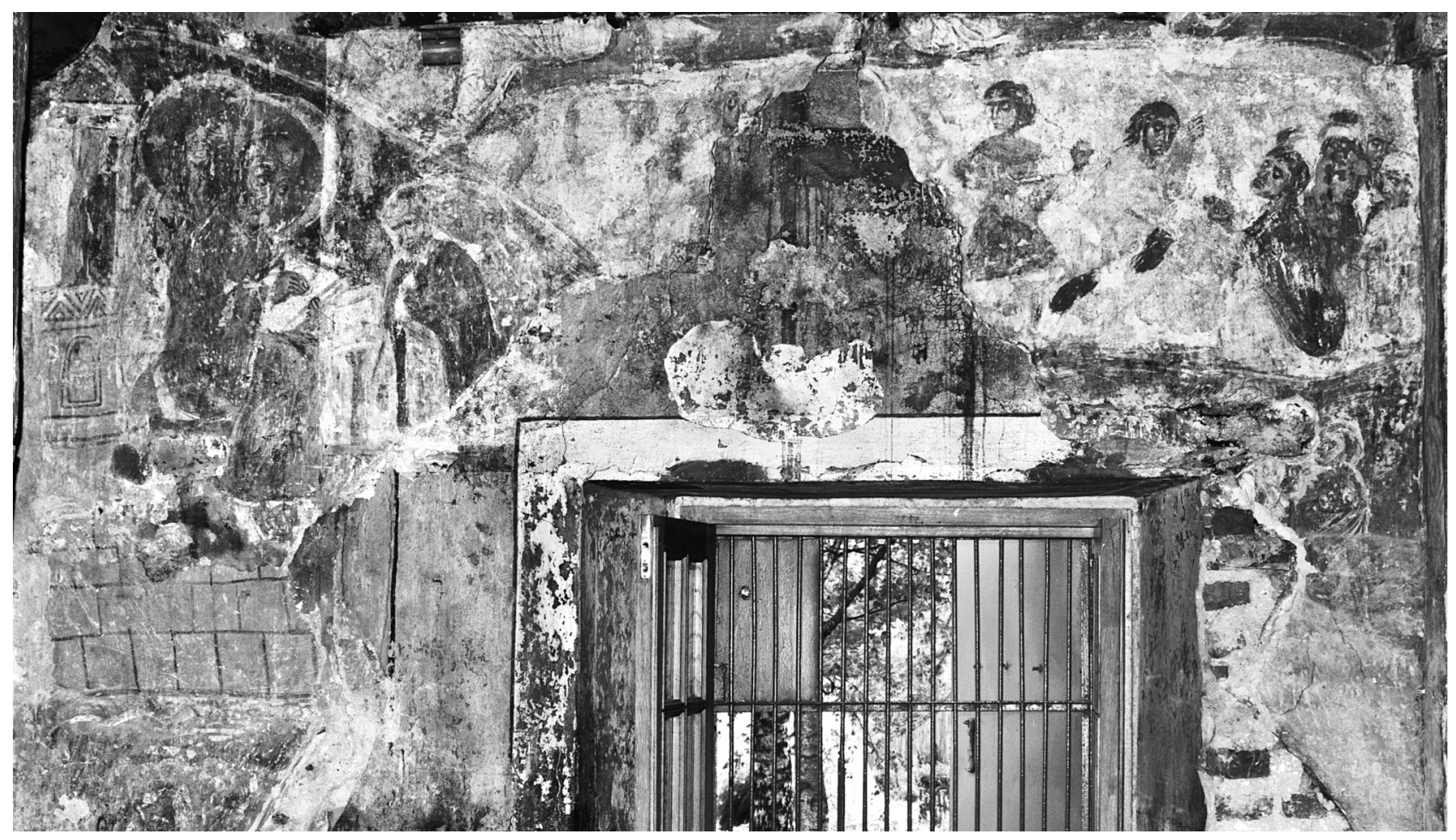

Fig. 2. Polotsk, monastery of Euphrosyna, church of the Savior. The "Source of Divine Wisdom" of Saint John Chrysostom. General view.

Fig. 3. Polotsk, monastery of Euphrosyna, church of the Savior. The "Source of Divine Wisdom" of Saint John Chrysostom. Apostle Paul, John the Chrysostom and Proclus.

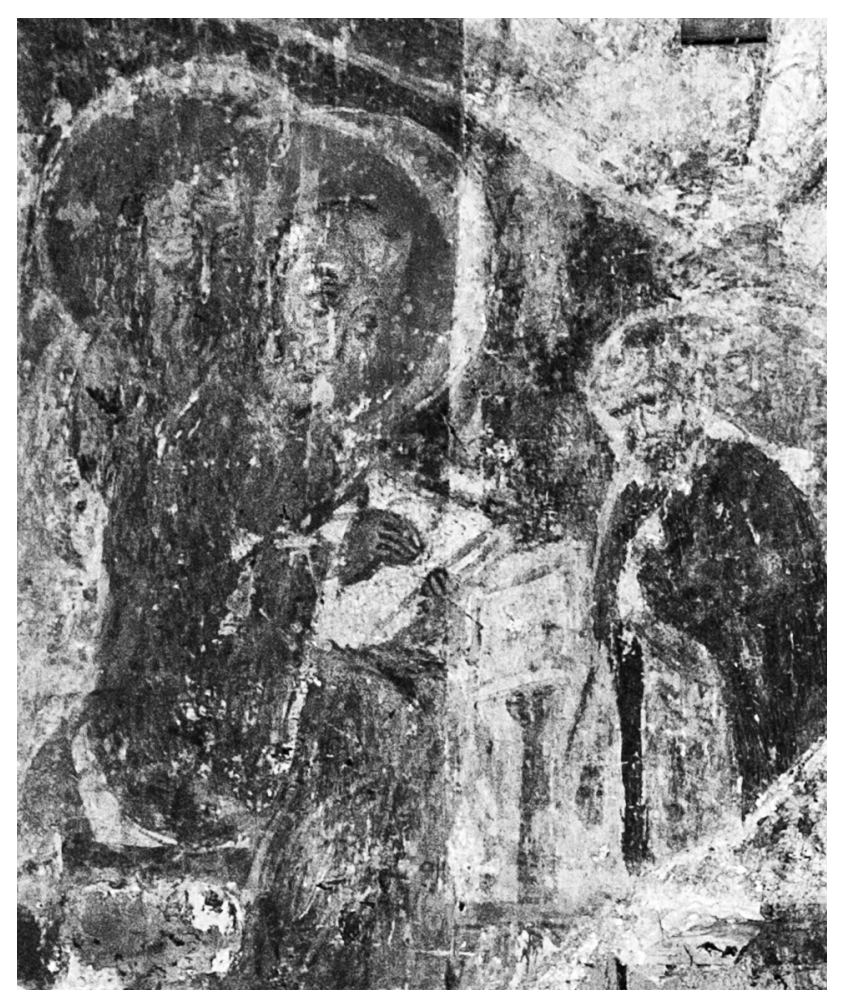

stands behind him and dictates in his ear. In the left part of the composition John's secretary and servant Proclus, who plays a major role in this scene, observes from behind a curtain that hangs in the architectural wing, indicating the entry to the bishop's cell (Fig. 3). According to his vita, Saint John, who was at that time Patriarch of Constantinople, worked hard on his commentary to the Epistles of Paul, and sought to confirm the correctness of his work. One night Proclus went to John's cell at the request of a visitor and found the Bishop working, as some elderly monk whom Proclus took for Saint Paul whispered in his ear. This vision, told to him by Proclus, convinced Saint John that his work was pleasing to God. A group of monks standing in front of John Chrysostom and listening to his teaching completes the scene. A stream of water flowing from under the desk is almost completely lost in the left part of the composition, but is still readable in its right part where it fills the lower corner of the scene. Two male figures, possibly monks, have survived here, drinking water, scooping it up with cups (Fig. 4). The meaning of the scene is explained in an extensive Slavic inscription, which can be partly read from the traces of the letters (Fig. 5). 




A similar scene opposite this composition is located on the north wall. It is based on an almost identical mirror scheme (Fig. 6), the only difference being that the main character here is Saint Gregory the Theologian, who receives a visionary admonition from John the Apostle. It is significant that there is no depiction of the figure of the Apostle, but only of his head, hanging over the Bishop in the form of a vision (Fig. 7). The picture is also followed by a Slavic inscription, only partly legible, which names both Gregory and John (Fig. 8). Like the scene opposite, there is a servant standing behind them and looking out from behind a curtain, while Gregory himself is addressing a similar group of monks (Fig. 9). A stream of water with a male figure holding a cup above it, as if it is flowing into the lower corner of the composition, can be clearly discerned in the left, better preserved part of the scene, as in the first case (Fig. 10). Typically, both compositions are perfectly symmetric, including the presence of Gregory the Theologian's inspirer the Apostle John, and the figure of the servant peeping out from behind the curtain, though the vita of Saint Gregory does not contain any such episode. ${ }^{2}$

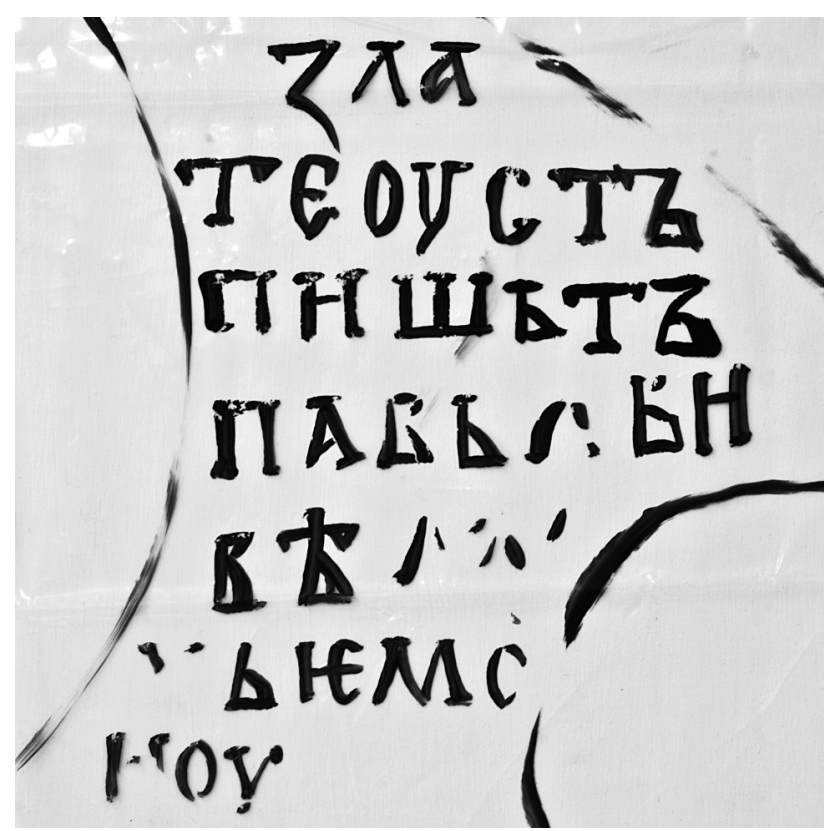

Fig. 4. Polotsk, monastery of Euphrosyna, church of the Savior. The "Source of Divine Wisdom" of Saint John Chrysostom. Two monks.

Fig. 5. Polotsk, monastery of Euphrosyna, church of the Savior. The "Source of Divine Wisdom" of Saint John Chrysostom. Drawing of inscription.

The idea of the Church Fathers' doctrine being the Source of Divine Wisdom can be traced through many literary monuments of different times. But the Bishops-Sources of Wisdom iconography itself only developed in the 12th century, based on an episode from the vita of John Chrysostom as mentioned above. Images of the Bishop, writing at the Apostle Paul's dictation in accordance with the vita episode, are known from Byzantine illuminated books since the 11th century, where they were placed in many different contexts. This scene appears as an illustration to the vita of John Chrysostom in many illuminated Menologia of Symeon Metaphrastes. ${ }^{3}$ It also appears in the Jerusalem Liturgical

\footnotetext{
${ }^{2}$ For the scenes of John the Theologian's vita see Ch. Walter, Art and Ritual of the Byzantine Church, London 1982, 100-103.

${ }^{3}$ Walter, Art and Ritual, op.cit. (n. 2), 48-49; N. Ševčenko, Illustrated Manuscripts of the Metaphrastian Menologion, Chicago - London 1990, 84-85.
} 


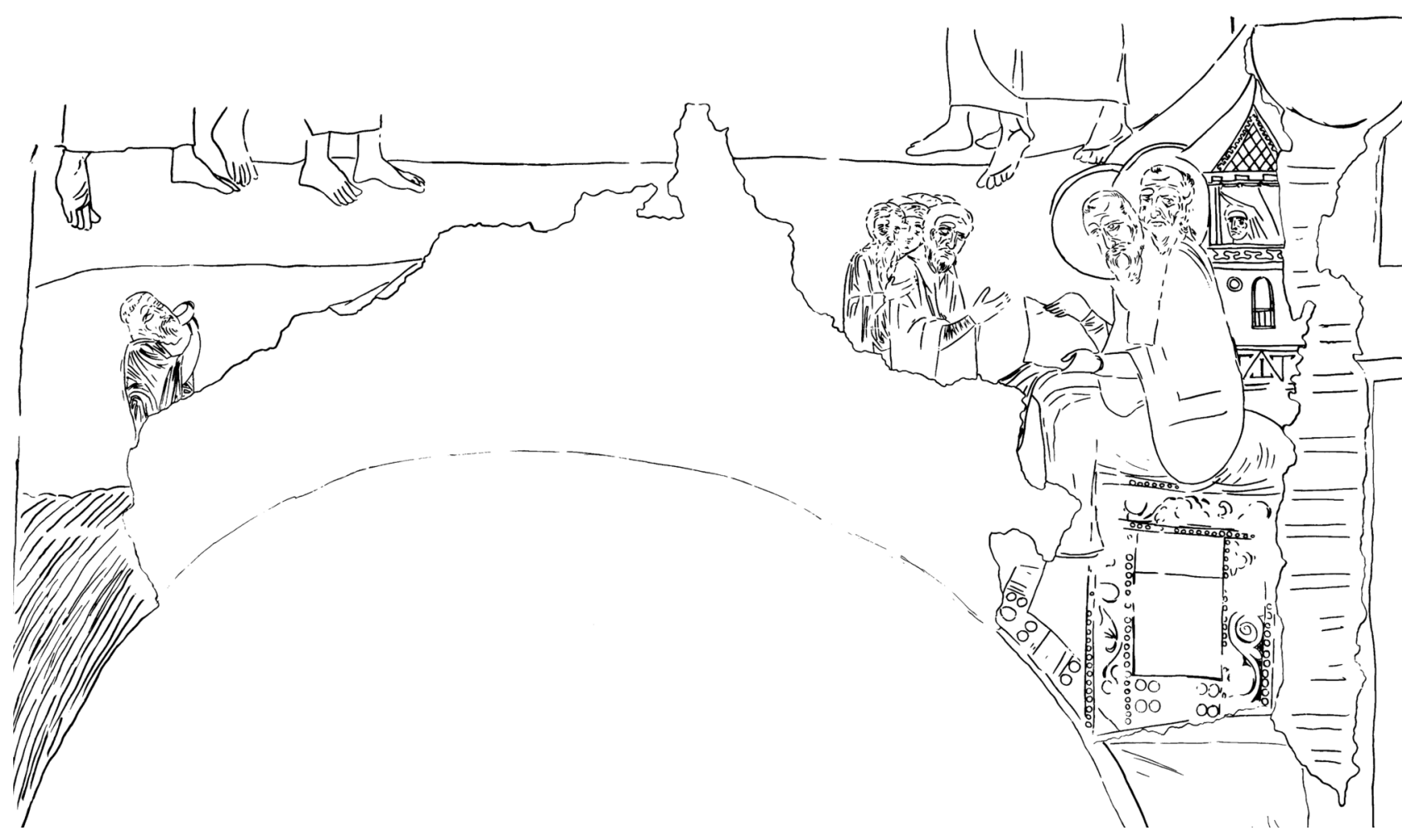

Fig. 6. Polotsk, monastery of Euphrosyna, church of the Savior. The "Source of Divine Wisdom" of Saint Gregory the Theologian. Drawing.

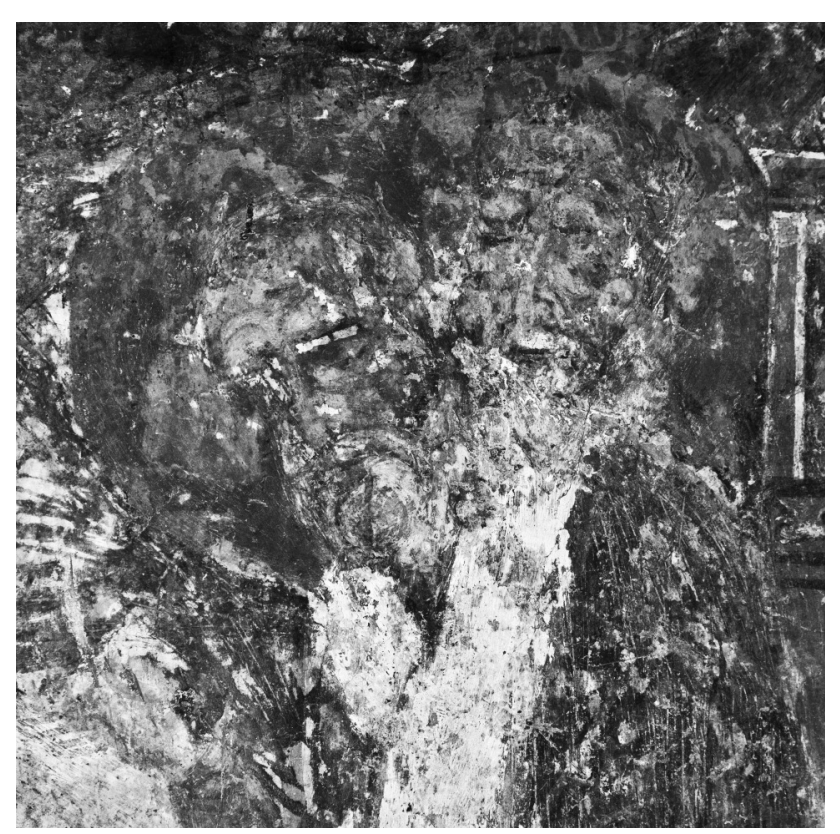

Fig. 7. Polotsk, monastery of Euphrosyna, church of the Savior. The "Source of Divine Wisdom" of Saint Gregory the Theologian. Saints John and Gregory the Theologian.

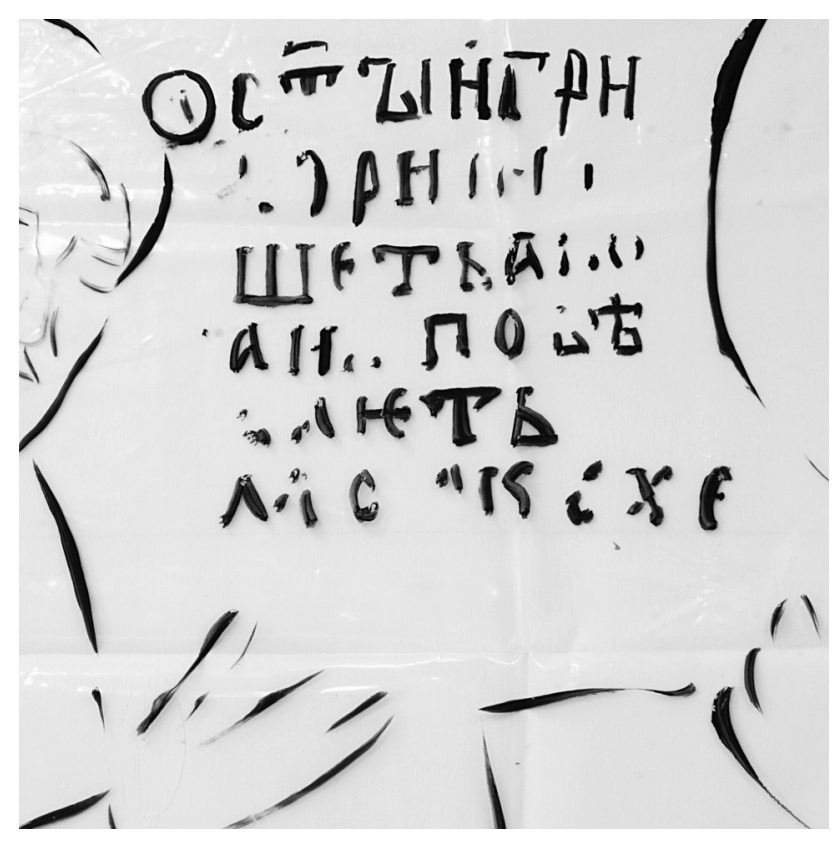

Fig. 8. Polotsk, monastery of Euphrosyna, church of the Savior. The "Source of Divine Wisdom" of Saint Gregory the Theologian. Drawing of inscription. 


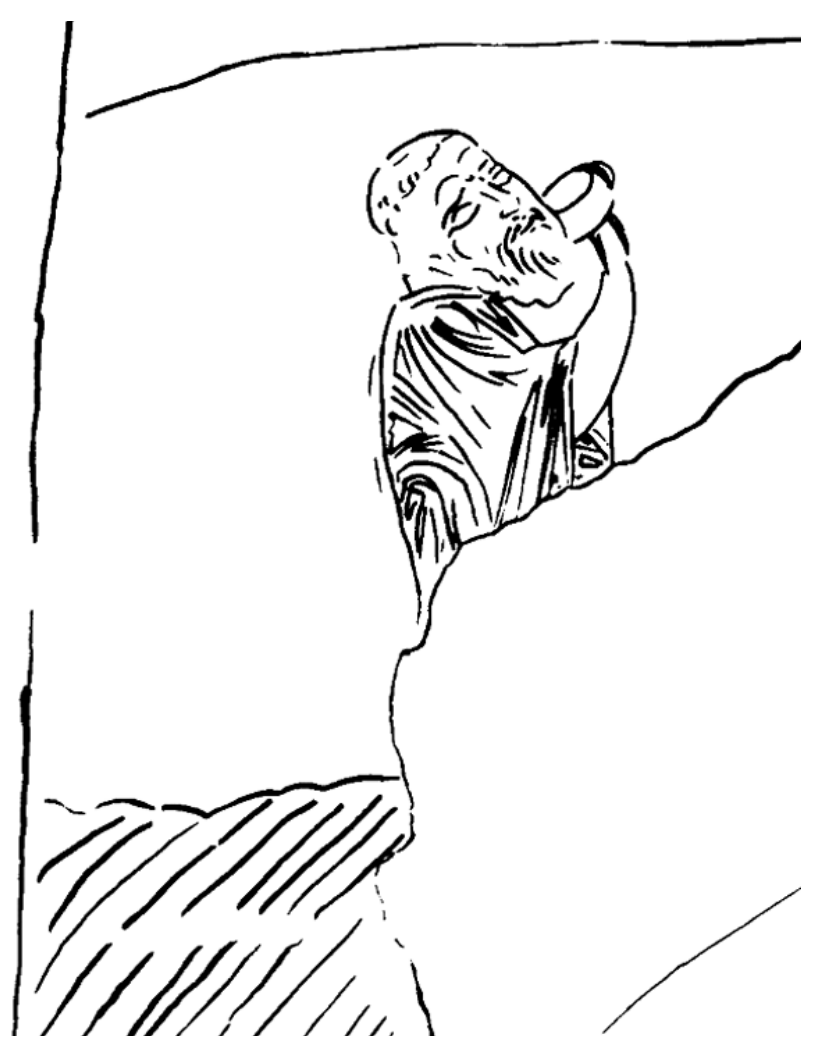

Fig. 9. Polotsk, monastery of Euphrosyna, church of the Savior. The "Source of Divine Wisdom" of Saint Gregory the Theologian. A drinking monk. Drawing (detail).

scroll, which dates to the end of the 11 th century, ${ }^{4}$ where it corresponds to the suffrage text after the Gospel reading, and in Psalter illustrations, where it accompanies the fourth strophe of the 49th Psalm: "My mouth will speak words of wisdom; the meditation of my heart will give you understanding" (Psalm 49:3) (Hamilton Psalter, fol. 109). ${ }^{5}$ There are instances when the scene with John Chrysostom appears out of the codex context, as for example in the 11th century Gospel from the Cambridge University Library (Cambridge, Univ. Lib. Add. 720 , fol. 133r). ${ }^{6}$ In all cases, however, the presence of three persons is essential: John Chrysostom, the Apostle Paul, and the Bishop's secretary Proclus, the future Patriarch of Constantinople.

Towards the end of the 12th century this scene was transformed into a new theme, which acquired the name John Chrysostom's Source of Wisdom, becoming established for the first time in the art of the second half of the 12th century. Examples include the miniature from the Homilies of John Chrysostom, dating from late 12th century, from the

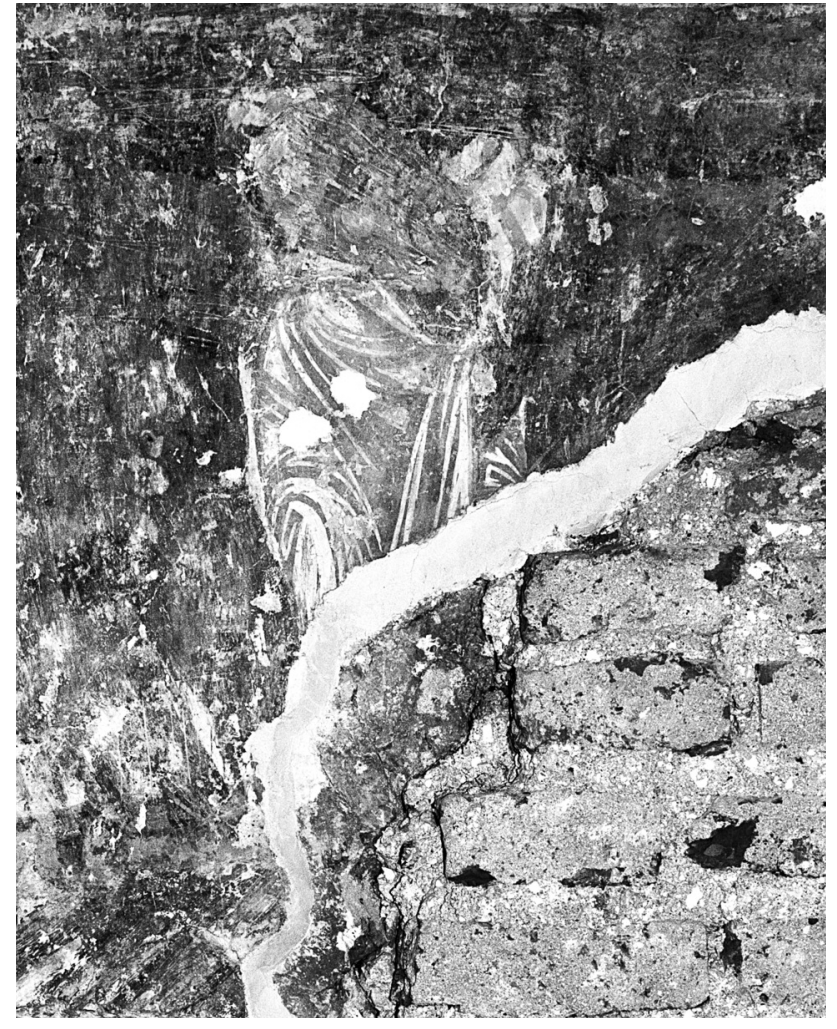

Fig. 10. Polotsk, monastery of Euphrosyna, church of the Savior. The "Source of Divine Wisdom" of Saint Gregory the Theologian. A drinking monk (detail).

Ambrosiana Library of Milano (Ambrosian. I 72 sup. (65), fol. 263v $)^{8}$ (Fig. 11). Among examples in 12th century monumental painting, the only known parallel to the Polotsk composition is a badly damaged fresco in the chapel of the

\footnotetext{
${ }^{4}$ A. Grabar, "Un rouleau liturgique constantinopolitain et ses peintures," L'art de la fin de l'antiquité et du moyen âge, Paris 1968, 477, pl. 125.

${ }^{5}$ Ch. Walter, "The Portrait of Jakov of Serres in London, Additional 39626," Zograf 7 (1976), 72.

${ }^{6} \mathrm{G}$. Galavaris, The Illustrations of the Prefaces in Byzantine Gospels, Wien 1979, 63-64, fig. 49. Galavaris erroneously interprets this miniature as a composition with figures of the evangelist Luke and his inspirer, the apostle Paul.

${ }^{7}$ For an overview of this theme see Ch. Walter, "Biographical Scenes of the Three Hierarchs," REB 36 (1978), 233-260.

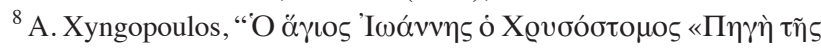

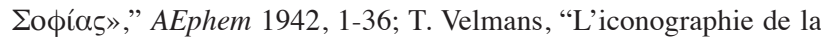
"Fontaine de Vie" dans la tradition byzantine à la fin de moyen âge," Synthronon, Paris 1968, 120-121; Walter, Art and Ritual, op.cit. (n. 2), 112-113
} 
Virgin in the monastery of Saint John the Theologian on Patmos (1176-1180), where the Source of Wisdom scene is added to the multi-faceted bishop's cycle in this chapel. ${ }^{9}$ The depiction of the stream of water coming from the book or the scroll and groups of people - usually clergy or monks drinking from the Source of Wisdom were the new iconographic elements.

Significantly, both versions of the scene with John Chrysostom existed simultaneously, and the choice of iconography was determined by the general programmatic context. When the scene belongs to the cycle of monastic deeds, the hagiographic aspect of the scene, which might rather be called "The Vision of Proclus," 10 is emphasized; in this case the water stream and the drinking figures are absent. An example of this iconographical version is the mural in the chapel of the Forty Martyrs church in Tŭrnovo (1230), where the scene with John Chrysostom is presented in a monastic cycle of neighboring compositions, "The Conversation of Anthony the Great and Paul of Thebes" and "Elijah the Prophet in the Desert." The latter may be interpreted as a universal prototype of an ascetic deed. "The Vision of Proclus" is included in the detailed Patericon cycle, which survived in the Hilandar catholicon (1325) murals, ${ }^{12}$ and in the less detailed monastic story in Blatadon cathedral in Thessaloniki (second half of the 14th century). ${ }^{13}$ In other cases the theme of the transferring of God's Grace through John Chrysostom is emphasized, and this version shows the Source of Wisdom, while the hagiographic aspect is downplayed and the figure of Proclus may be even absent. To such examples belongs the mentioned painting from the monastery of Saint John the Theologian in Patmos, where this composition corresponds with the figures of bishops, which are of programmatic significance in this chapel.

The second version of this scene in particular became the basis for development of an entire iconographic group united under the theme of the Source of Wisdom. Along with John Chrysostom others can be presented in these scenes in a similar iconographic scheme, including Basil the Great, Gregory the Theologian, and Athanasius of Alexandria. Such cycles are known from four famous monuments of the Late Middle ages: the murals of Saint Michael's church in Lesnovo (1349) ${ }^{14}$ (Fig. 12), Saint Nicholas church in Psača (1365-1371), ${ }^{15}$ Poganovo monastery cathedral (1499) ${ }^{16}$ (Fig. 13), and Pherapontovo monastery cathedral (1502). ${ }^{17}$ In all cases the compositions are located in the upper zones of decoration. In Lesnovo four scenes with the named bishops are

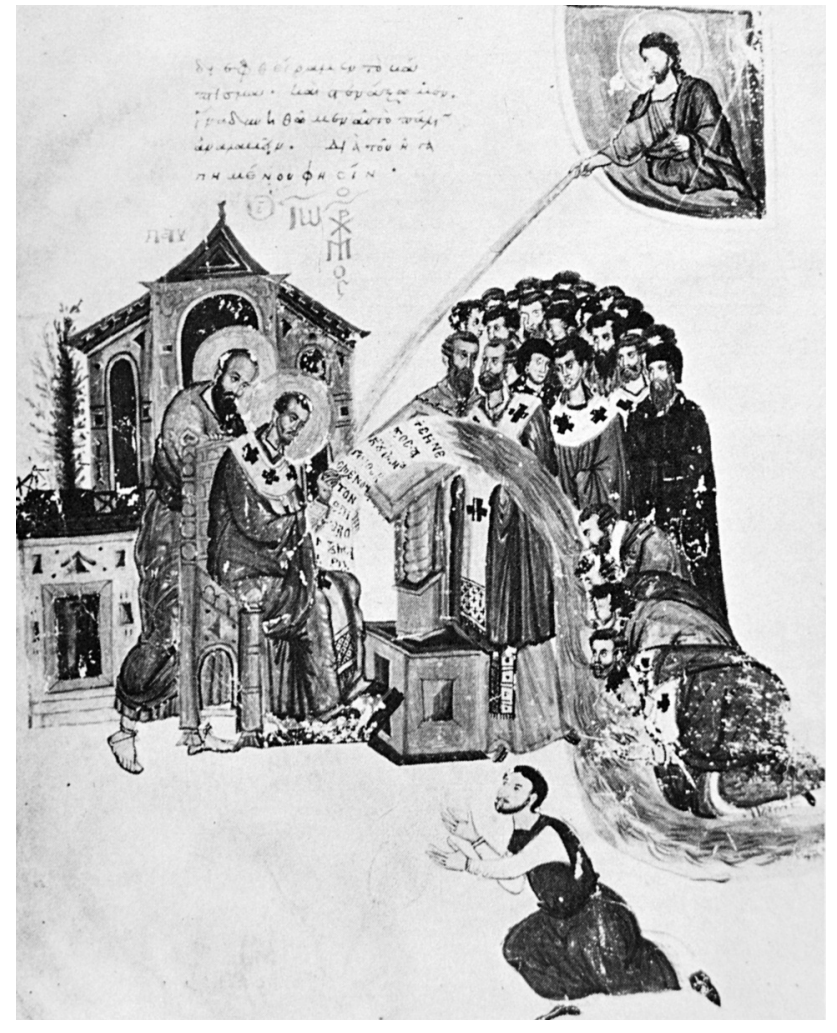

Fig. 11. Milano, Ambrosiana I 72 sup. (65), fol. 263v. John Chrysostom's "Source of Wisdom."

\footnotetext{
${ }^{9}$ E. Kollias, Patmos. Byzantine Art in Greece (Mosaics - Wall Paint-

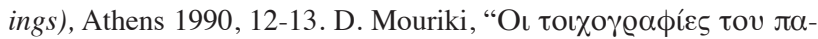

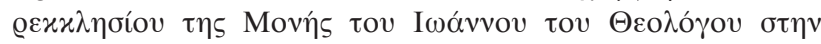

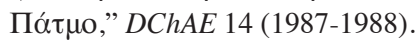

${ }^{10}$ A. Mitsani, "The Vision of Proclus in Miniatures of Metaphrastian Menologia,” $A D 40$ (1985), Meletes, 148-161.

${ }^{11}$ B. Penkova, "Kom idejno-soderzhatelnaja kontekst na stenopisite ot tserkvata 'Sveti chetiredesiat muchenitsi' v Veliko Tirnovo," Paleobulgarica XIX (1995), 4, 75-91

${ }^{12}$ M. Markovich, "Illustratcije paterichkihpricha u priprati Hilandarskogo katolikona," Osam vekova Hilandara, Belgrade 2000, 59; Penkova, op.cit. (n. 11), fig. 8.

${ }^{13}$ S. E. J. Gerstel, "Civic and Monastic Influences on Church Decoration in Late Byzantine Thessalonike,” DOP 57 (2003), 236-237, fig. 16.

${ }^{14}$ S. Gabelić, The Monastery of Lesnovo, History and Painting, Belgrade 1998, 162-167, fig. 74-77.

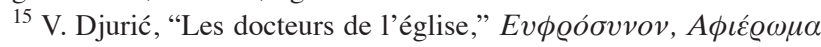

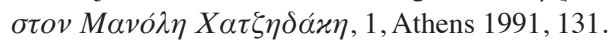

${ }^{16}$ A. Grabar, La peinture religieuse en Bulgarie, Paris 1928, 338, pls LVII-LVIII; Velmans, op.cit. (n. 8), 126-127; Djurić, op.cit. (n. 15), 129-135.

${ }^{17}$ T. Mikhelson, "Tri compozitssii na temu 'Sobortriekhsviatitelej' v rospisiakh Ferapontova monastirija,” DRI, Monumental nai ja zhivopis XI-XVII vekov, Moscow 1980, 324-342.
} 


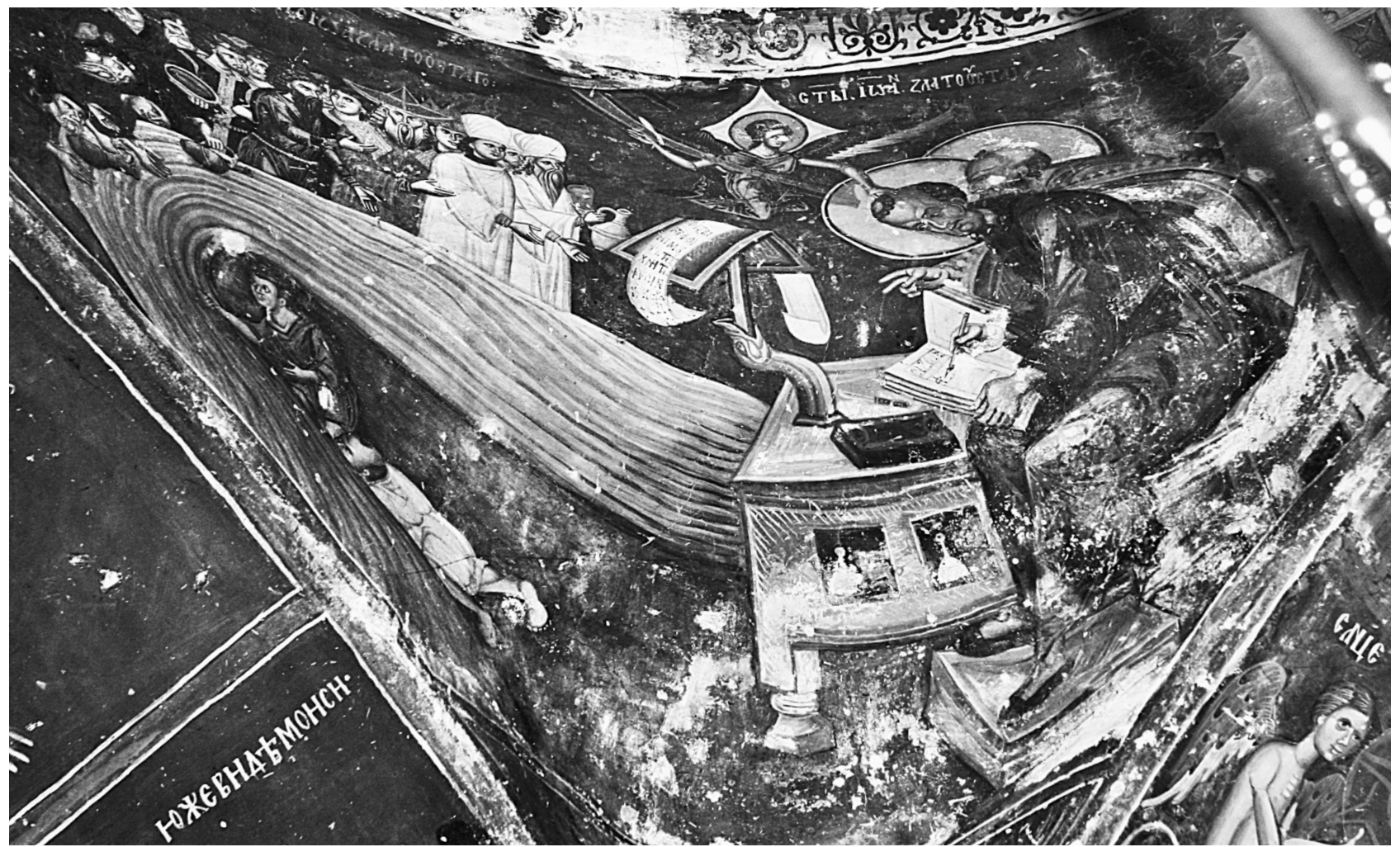

Fig. 12. Lesnovo, church of the Archangel Michael (1349). The "Source of Divine Wisdom” of Saint John Chrysostom.

located in the pendentives of the dome rising above the narthex. All four scenes are presented in an expanded iconography: John is shown with the Apostle Paul, and other bishops are accompanied by angels with Divine halos. Large groups of monks and clergy are drinking from the flowing waters of Wisdom. Slavonic inscriptions identify the traditional names of these compositions: the "Teaching of Saint John Chrysostom," the "Teaching of Athanasius the Great," etc. The compositions in the Saint Nicholas church in Psača are similarly situated. In Poganovo monastery cathedral with its triconch plan, two compositions occupy the conchs of the side bays, adjacent to two scenes of the cycle of the Virgin; the south carries the scene of John Chrysostom and the Virgin's Nativity, and the north, Gregory the Theologian and the Presentation of the Virgin. Both scenes have captions which define them with another canonical name: "The Source of Wisdom." Finally, in Pherapontovo monastery cathedral similar scenes with the three hierarchs Basil the Great, John Chrysostom, and Gregory the Theologian are located in the lunettes under the west, north, and south dome arches. These compositions are untitled, with only the names of the bishops inscribed.
Prevailing opinion would have it that the group images of bishops in the Source of Wisdom iconography appear in monumental painting only in the Palaiologan period, ${ }^{18}$ but the murals of the Polotsk monastery Savior church are evidence that such mini-programs had become widespread in the Middle Byzantine period. Basically, this iconography shows the general scheme, representing a Church Father as teacher and preacher, writing down his works, inspired by God. The first images of this kind in church decoration would be the Evangelists in the pendentives. Their images in "teaching" iconography, that is sitting behind a desk and recording the Gospel texts, though well known in Byzantine and West European miniature painting as early as the Early Christian period, appeared in monumental painting quite late. The earliest surviving examples of this type are the mosaics of Saint Sophia in Kiev ( $c a .1130)$ and in the Nea Moni catholicon (1049-1055). It is quite possible that figures of other Church

\footnotetext{
${ }^{18}$ See for example: Walter, Art and Ritual, op.cit. (n. 2), 114
} 


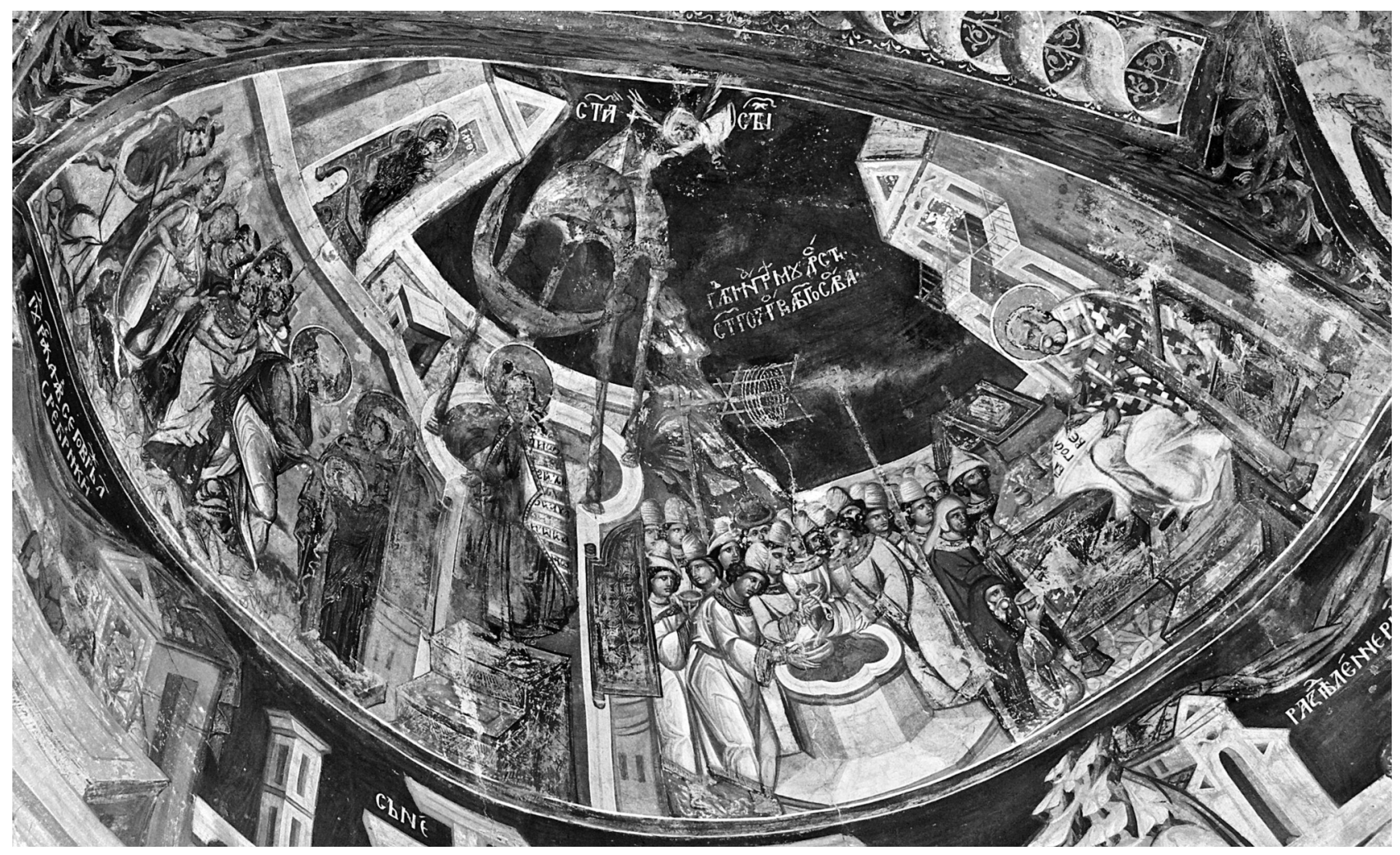

Fig. 13. Poganovo monastery cathedral (1499). The "Source of Divine Wisdom" of Saint Gregory the Theologian.

teachers were appearing in this iconographic scheme on the pendentives of the side domes in multi-domed churches erected in different regions of the Byzantine world. It is significant that churches with several domes became especially popular in Russia, where in the second half of the 11th and early 12 th centuries a number of colossal multi-domed churches were erected. Unfortunately, neither of them preserved any paintings in the pendentives of the side domes, but the extent of this iconographic scheme as applied to the paintings in the pendentives of the side domes in the monuments of Palaiologan art, for example in the church in Lesnovo, indirectly tells us that it is quite old. Besides, the iconography of the Church Father as teacher and writer was widely used in the Middle Byzantine period. Not only the Evangelists, but also bishops, hymnographers, and monkswriters were often presented in such "teaching" iconography. The 12th century Gospel miniatures from the Pantokrator monastery on Mt Athos (cod. 234) showing not only the Evangelists, but also the Apostle Paul, Gregory the Theologian, and Athanasius of Alexandria in such iconography of writers-teachers can serve as a good example. ${ }^{19}$
In the first place the figures of three bishops would occupy the pendentives of the side domes, accordingly to the unusual growth of their worship exactly in the 11th century. "Three bishops" Basil the Great, John Chrysostom, and Gregory the Theologian are worshipped by the Orthodox Church as great teachers, theologians, and creators of the holy liturgy, inspired by the Holy Spirit. Their special glorification is mainly related to Mauropous, bishop of Euchaita, who lived in the 11th century. When, according to tradition, an argument occurred concerning which bishop was to be worshipped first, the bishops came to him and pointed out their equality. It was then that the day feast of the Three Hierarchs, for which John Mauropous had written a service, was established. Their triple image was very widespread in Byzantine art. ${ }^{20}$ In the Lesnovo murals of Saint Michael's church they are presented

\footnotetext{
${ }^{19}$ S. M. Pelekanidis - P. K. Christou - Chr. Mauropoulou-Tsioumi S. N. Kadas - A. Katsarou, Treasures of Mount Athos: The Illuminated Manuscripts, 3, Athens 1979, figs 242-247, 252, 256.

${ }^{20}$ Walter, Art and Ritual, op.cit. (n. 2), 111-115.
} 


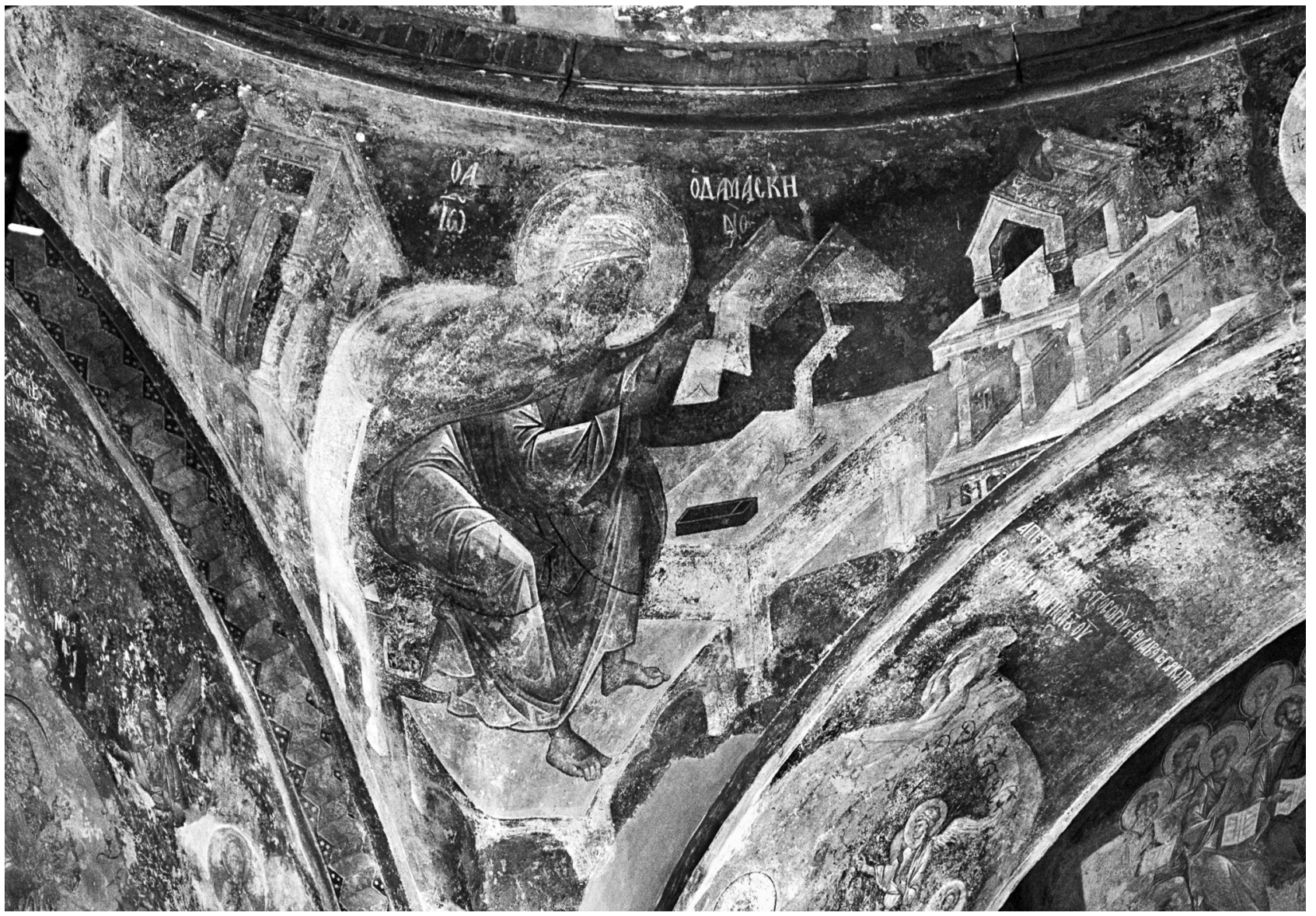

Fig. 14. The paraclession of Kariye Camii (ca. 1320). Saint John of Damascus.

in iconography of Sources of the God's Wisdom together with Athanasius of Alexandria, who is also worshipped as one of the greatest teachers of Church.

Among other examples, the paintings of the Saint Trinity Pareclession in Kariye Camii (ca. 1320) are of significance. Here in the pendentives the hymnographers John of Damascus, Kosmas of Maiouma, Joseph, and Theophilos ${ }^{21}$ (Fig. 14) appear in similar "teaching" iconography. Another example are the paintings of Blatadon monastery in Thessalonike (second half of 14th century), where the south pareclession pendentives carry the figures of John Chrysostom and Symeon the Younger, Gregory the Theologian, and Gregory Palamas. ${ }^{22}$ Two figures of John Chrysostom with the Apostle Paul and another unknown hymnographer have also survived in the upper zone of the decoration in the church in Calendžicha (1384-1396). ${ }^{23}$ John Chrysostom, being taught by the Apostle Paul, is also shown in a similar series of hymnographers in Hagia Paraskevi Geroskipou on Cyprus (15th century) ${ }^{24}$ (Fig. 15). This scheme became very popular in the Late Middle Ages. There are many such examples in 16th century Romanian murals, where the pendentives of the west domes above the narthex are normally occupied by the figures of four hymnographers: John of Damascus, Kosmas of Maiouma, Joseph, and Theophilos, and sometimes also John Chrysostom with the Apostle Paul. Such is the case, for instance, in the churches of Saint George (1514-1522) and Saint Demetrius (1535) in Suceava, in the monasteries of

\footnotetext{
${ }^{21}$ P. A. Underwood, The Kariye Djami, New York 1966, I, 219-222; III, 336-339.

${ }^{22}$ Gerstel, op.cit. (n. 13), 236.

${ }^{23}$ I. Lordkipanidze - M. Janjalia, Tsalenjikha, Wall Paintings in the Savior's Church, Tbilisi 2011, fig. 109.

${ }^{24}$ A. and J. Stylianou, The Painted Churches of Cyprus, Treasures of Byzantine Art, London 1997, 385, fig. 230.
} 


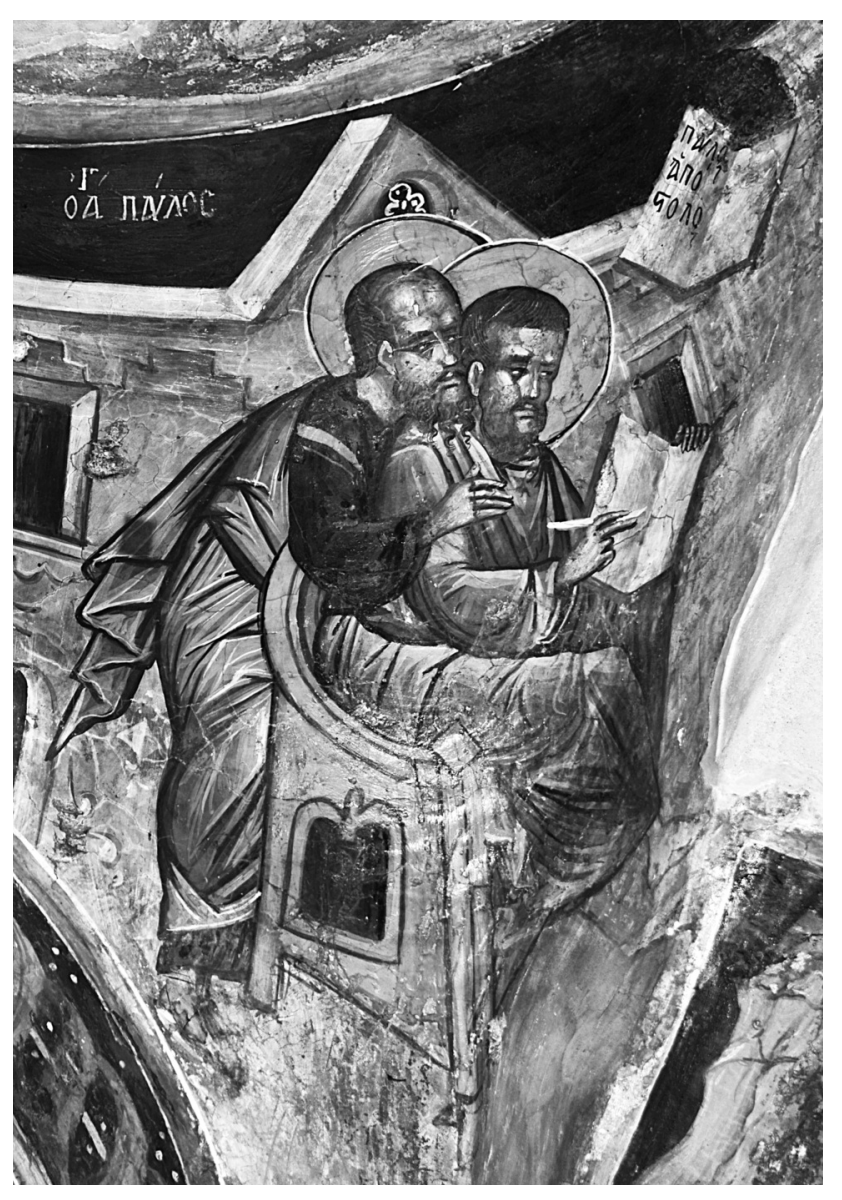

Fig. 15. Cyprus, church of Hagia Paraskevi Geroskipou (15th century). Saint John Chrysostom with the Apostle Paul.

Snagov (1521), Khumor (1535), Voronet (1547-1550), and Sucevitsa (1601), and elsewhere.

Both scenes discovered in the church of the Savior in the monastery of Euphrosynia, as noted above, are based on a mirror scheme, though unlike the one with John Chrysostom, in the case of Gregory the Theologian there are no grounds in the vita for the figures of the Apostle and the servant to be shown. Their presence in the scene with Gregory the Theologian indicates very clearly the development of this type of iconography. Obviously, the John Chrysostom composition served as a prototype for the general Sources of Wisdom iconography, while similar scenes featuring bishops only reproduced the scheme, and sometimes quite loosely, as shown by the painting in the Savior's church. If the Apostle John is introduced into the scene of Gregory the Theologian to indicate inspiration from God, the figure of the servant was probably inserted only to make the iconography completely iden- tical. A similar iconographic method can be seen in a number of Middle Byzantine miniatures, where the established way of presenting one of the Evangelists is also applied to the other Gospel authors. Thus, one of the miniatures in the Mt Athos Pantokrator monastery Gospel (cod.234, 12th century) shows John the Theologian dictating to his pupil Prochorus, according to the strong iconographical tradition. In this same manuscript there is a scene of similar iconography, but with the Apostle Luke instead, shown dictating to an unknown youth who appears to be his secretary ${ }^{25}$ (Figs 16, 17). This example reveals the way the medieval artist used some iconographic patterns, giving them meanings which did not always correspond with the literary sources. ${ }^{26}$ Such interpolation, typical for Byzantine miniatures, appears clearly in the composition of both scenes in the Polotsk church, once again showing the influence of manuscripts on the iconographic program of the Savior's church.

However, the programmatic significance of these scenes seems to be the main thing about such reproduction of the pattern: they develop the idea of a gradual descent of Divine Wisdom from the Apostles to the bishops and thence to all the monks. The figure of the Apostle John presented in the scene of Gregory the Theologian is "uncanonical" in terms of the literary grounds offered by the vita, but shows that special meaning reasons were prevailing in the iconography of this representation. It is significant that there are no examples known of this type of composition with such "loose" iconographic organization of this scene. The most popular pattern would be the one with figures of bishops and Wisdom's angels, as in the early example in the church of the Archangel Michael in Lesnovo. This scheme became popular in Russia, too, where the theme of "Sophian" inspiration was developed in a number of 14 th and 15 th century monuments. Several examples may be mentioned: the paintings of the Dormition church in Volotovo (1363), where the pendentive scenes with Evangelists and the allegorical-symbolic compositions of the narthex reproduce the personification of the young Sophia several times; ${ }^{27}$ a number of 14 th-16th century miniatures, originating mostly from Novgorod, with the images of Evangelists in the same iconographic pattern and with Sophia as an

\footnotetext{
${ }^{25}$ Pelekanidis - Christou - Mauropoulou-Tsioumi - Kadas - Katsarou, op.cit. (n. 19), vol. 3, figs 243, 244.

${ }^{26}$ Galavaris, op.cit. (n. 6), 62-63, figs 45-48.

${ }^{27}$ G. Vzdornov, Volotovo. Freski tserkvi Uspenijana Volotovom Poliebliz Novgoroda, Moscow 1989, cat. nos 20, 21, 22, 181.
} 


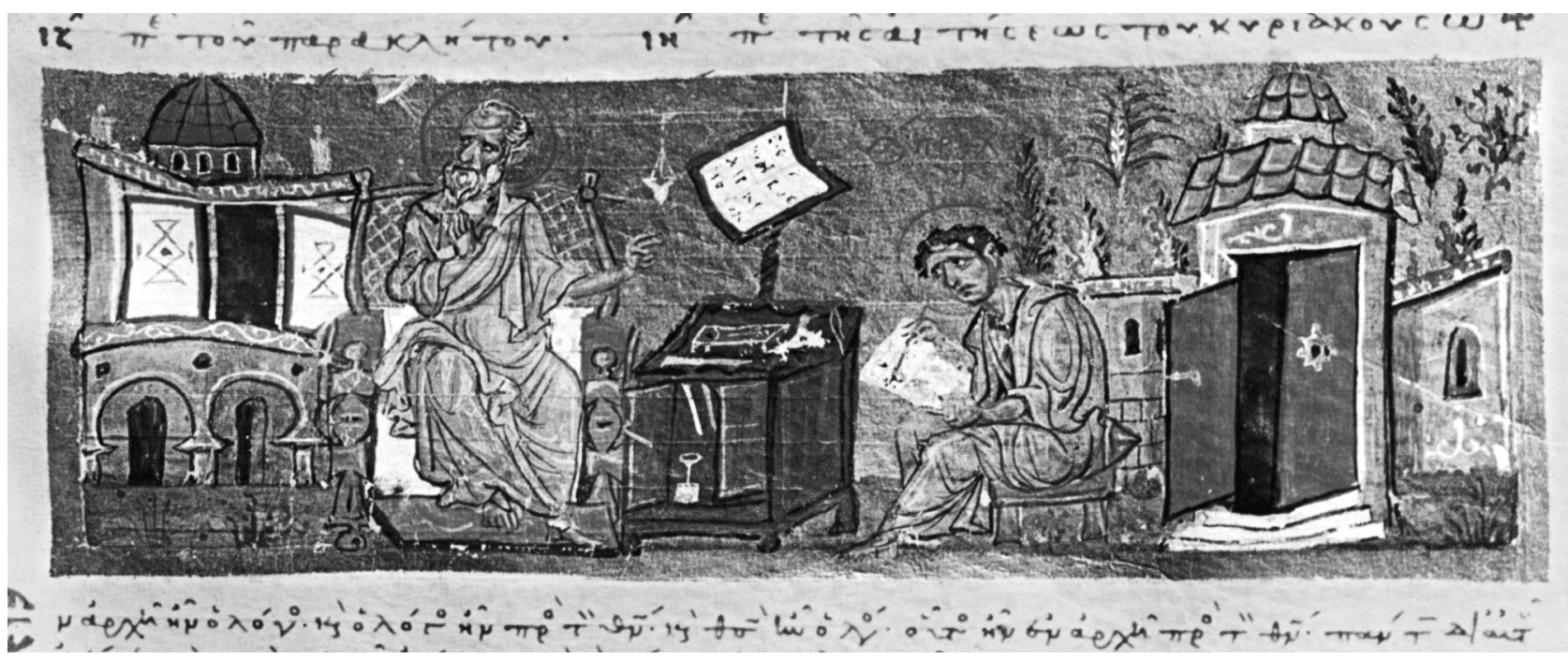

Fig. 16. Athos Pantokrator monastery, cod. 234, fol.31a. Evangelist John with Prochoros.

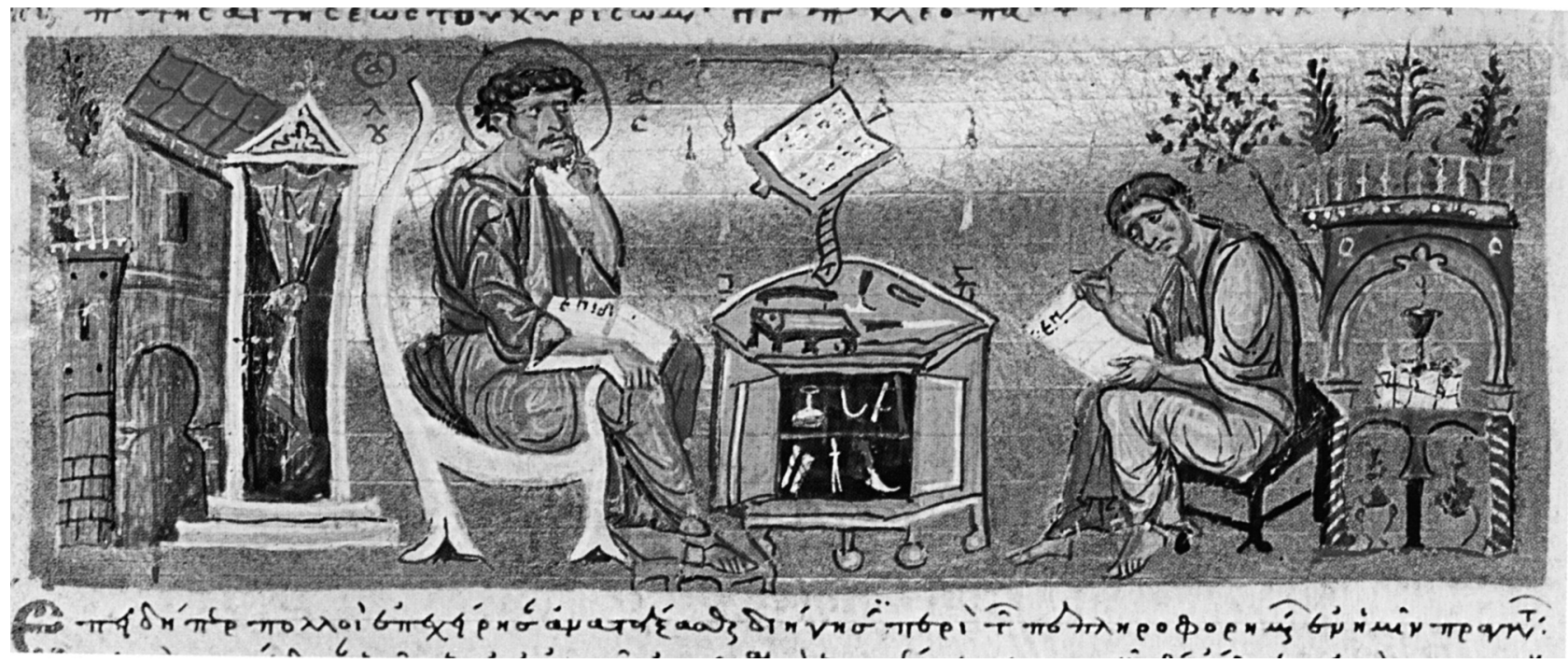

Fig. 17. Athos Pantokrator monastery, cod.234, fol.43a. Evangelist Luke with secretary.

inspirer, ${ }^{28}$ and even the very fact of the popularity of the Novgorod "Sophia the Wisdom of God" pattern in the 15th century. The story of Luke the Evangelist painting the image of the Virgin, inspired by a "Sophian" angel, became very popular in Old Russian and mainly Novgorod art, which is significant in this regard.$^{29}$ Even in those rare cases where Russian artists referred to the subject of the "Sources of God's Wisdom," they used the same iconography with an image of Sophia, as in the "Words of Gregory the Theologian" miniatures (1480-1490) (Fig. 18). Unlike the examined monuments from different periods, the mirror compositions of the Sources of Wisdom in Polotsk stand somewhat apart from the Byzantine and ensuing Russian traditions, and present an individual singularity of iconography which refers us once again to the

\footnotetext{
${ }^{28}$ One of the earliest examples of this theme in Old Russian manuscripts is the Evangelist Luke from the Lectionary of Moscow University Library (late 14th century). See O. Popova, Russian Illuminated Manuscripts of the 11th to the Early 16th Centuries, Leningrad 1984, fig. 35 .

${ }^{29}$ E. Smirnova, "Smotrijana obraz drevnikh zhivop istsev ...". Tema pochitanijaikon v iskusstve Sredne vekovoi Rusi, Moscow 2007, 106-134.
} 


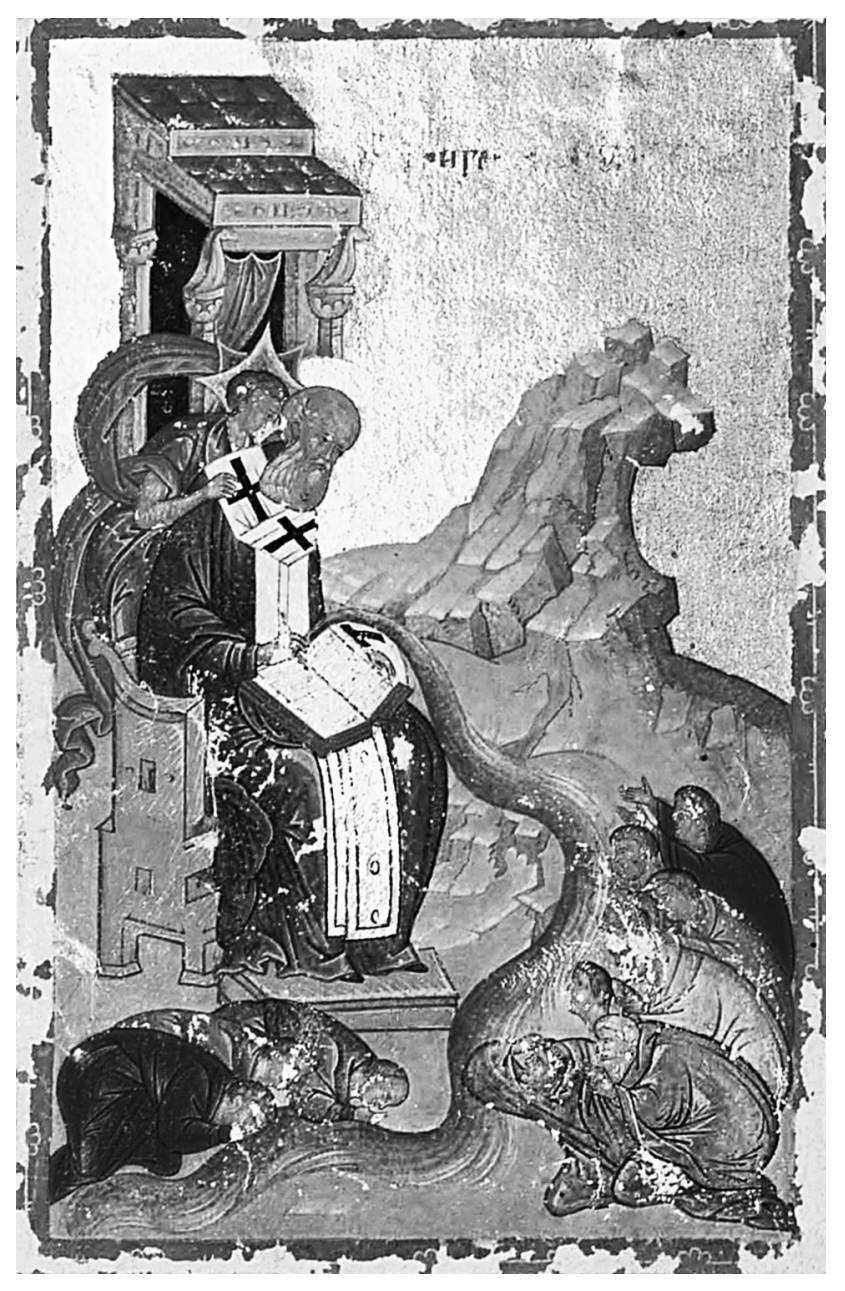

Fig. 18. Moscow State Library, Troitsk. 137. The "Source of Divine Wisdom" of Saint Gregory the Theologian, Words of Saint Gregory the Theologian.

figure of Saint Euphrosynia, who commissioned and compiled the program of the decoration in the Savior's church.

The sole (though probably, fundamental) iconographic distinction between the two scenes is the type of vestments the bishops wear. John Chrysostom has a simple monk's paramand and a mantle, which is usual in compositions where he is presented as a monk. At the same time, Gregory wears a bishop's omophorion over a similar vestment, which clearly indicates him as a bishop. Remarkably, such things are also emphasized in other examples of this type of composition. Thus for example, John Chrysostom in the above-mentioned 12th century miniature from the Ambrosiana Library in Milano is wearing full bishop's vestments, but then, it is mostly bishops who are listening to him. On the other hand, all the bishops in Saint Michael's church in Lesnovo are shown in simple monastic gar- ments. In Polotsk this emphasis on the distinction between garments seems to serve as a differentiation of the ways by which the bishops gained their supreme Wisdom through the Apostles. Thus, the figure of John implies the grace of a personal ascetic deed, while Gregory's image suggests the grace of bishops.

This vivid comparison of John Chrysostom and Gregory the Theologian, monk-bishop and bishop-monk, is in complete harmony with the content of the entire decoration, where monks and bishops prevail over other Saints. Indeed, the bishop's cycle in the Savior's church deserves its own study as a unique phenomenon. The figures of bishops occupy two lower zones of the altar. The traditional bishop's row takes up the lower zone of the apse, but its centre above the synthronon is occupied by the (enthroned?) image of Jesus Christ the High Priest with two angels, anticipating the iconography of the famous figure in the Savior's church on Nereditsa (1199). The row is enlarged with six scenes, presenting different bishops as healers, martyrs, fighters for the purity of faith, visionaries, honored with revelation from God. Besides, there are figures of bishops not only in the altar window intrados, but also in the prothesis and diaconicon, thus forming one program with the central apse paintings. The reason for the attention paid by Saint Euphrosynia to the bishops was probably the fact that the Savior's church was built near Saint Gregory's cathedral, the so-called "Burial Church" which had not survived (second half of 11th century), where the burial for all Polotsk bishops was displayed. As for the monastic cycle, which occupied almost the entire lower zone of decoration, it is exceptional in terms of completeness and variety of ways this subject is developed. It includes not only single figures on the sides of the four western pillars, but also scenes from the patristic cycle on the side bay's vaults, and scenes of monks' deeds in the gallery of the second floor as well where they are grouped around the entrance to "Saint Euphrosynia's cell."

One may say that both scenes, where the revelations of John Chrysostom and Gregory Theologian are placed on one semantic level, equate a monastic deed with a bishop's duty by making one hierarchical chain of these two categories of sanctity; thus these scenes are interpreted in a way that goes beyond traditional iconography. There are examples of two sanctity categories interpenetrating each other in such way in various Byzantine monuments. Thus in the monastery of Saint Chrysostomos in Koutsovendis, Cyprus (ca. 1100), the bishops in monks' garments - John Chrysostom, Gregory Theologian, Athanasius of Alexandria, Gregory of Agrigentum, Gregory of Omirits, and Gregory the Miracle-Worker - 
are placed in a series of monks ${ }^{30}$. V. Djurić, who studied this subject, mentions a similar example in Zrze (1368/9), where the Three Hierarchs and Nicholas of Myra are in the same monastic iconography ${ }^{31}$ (Fig. 19). Russian art gives an example of this phenomenon in a number of vita icons of Nicholas of Myra which also represent him in monk's garment. ${ }^{32}$

The display of the compositions in the Savior's church itself shows that these scenes were used in various contexts, and their place was not merely the side dome pendentives. The above-mentioned scene of "John Chrysostom the Source of Wisdom" in the monastery on Patmos demonstrates how this composition could be inserted into the expanded bishop's program, mostly influenced by the nature of order in its content. ${ }^{33}$ In Polotsk we probably have a similar case, though the scenes are used in a different sense, connected with the burial nature of the Savior's church. Together these compositions make a very effective pairing: directed from the altar to the main space of the church, they refer with a sermon to the congregation from the lower zone of the decoration. At the same time these scenes have a more specific recipient, as they are actually framing two arcosolia in the lower south and north walls. The streams of water originally washing the vaults of arcosolia are interpreted in such a context as sources of resurrection and eternal life for a person, who would drink from the Source of Divine Wisdom. Such a version corresponds fully with the words of the Gospel: "But whosoever drinketh of the water that I shall give him shall never thirst; but the water that I shall give him shall be in him a well of water springing up into everlasting life" (John 4:14).

The Savior says this to the Samaritan woman whom $\mathrm{He}$ met by the well, and it is precisely this scene of "Christ and the Samaritan" which appears in the middle zone of the north wall of the diaconicon (Figs 20,21) near the composition "John Chrysostom Source of Wisdom;" the two were divided only by the altarpiece which once existed here. It seems that "Christ and the Samaritan" scene developed in iconographical programs of the Middle Byzantine period as a liturgical image. Anthony of Novgorod noticed this rare episode when he visited the church of Saint George in Mangana, which was apparently decorated in the second quarter of the 11th century and included this composition in the altar area. ${ }^{34}$ The scenes from Genesis which symbolize the Eucharist such as "Abraham's Sacrifice," "The Three Young Men in the Fiery Furnace," and "Daniel in the Lion's Den" prevail in the diaconicon decoration, which is quite typical for this sacral space; the scene with the Samaritan, since it is included in the narrative

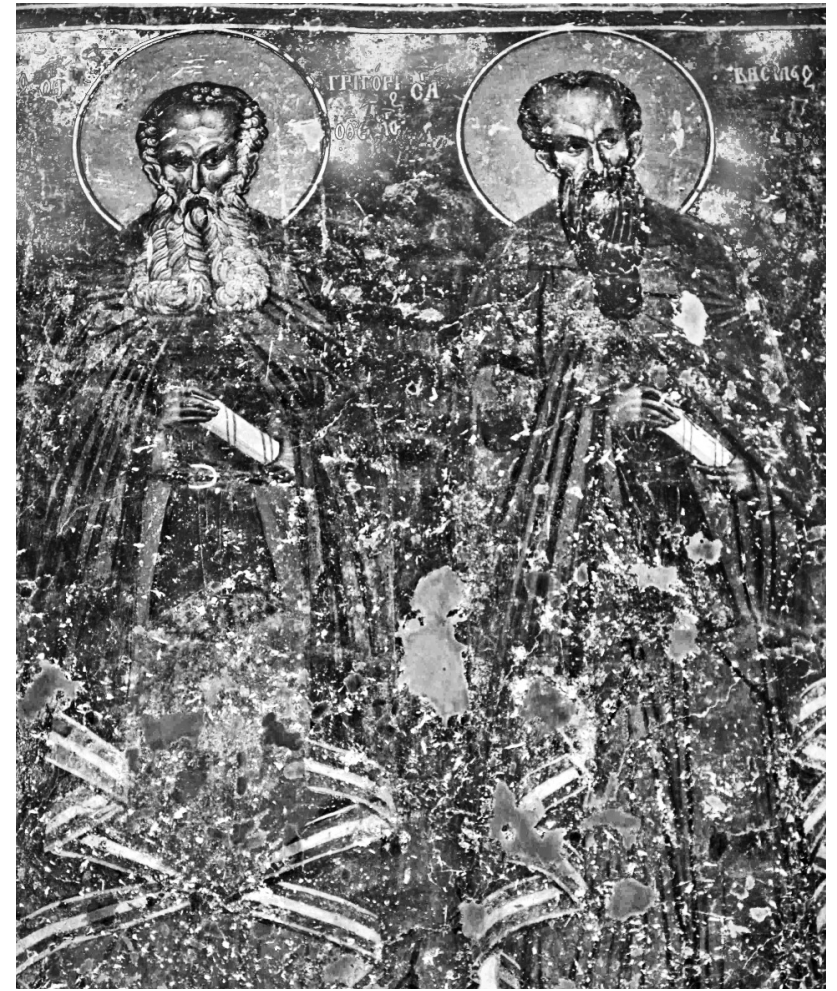

Fig. 19.Zrze, the Transfiguration church (1368/9). Saint Gregory the Theologian and Saint Basil the Great.

line, is definitely to be interpreted symbolically in connection with the liturgical program of the south apse. Besides, the idea of the "spring of eternal life" is shared by the Samaritan episode and the bishops - Sources of Divine Wisdom compositions, so they stand on the same symbolic level.

The liturgical meaning of both scenes is once more emphasized by the compositional approach. As was already noted, the scenes are not divided by any horizontal borders, but enter the scenic space of the Nativity and the Dormition above.

\footnotetext{
${ }^{30}$ C. Mango, "The Monastery of St. Chrysostomos at Koutsovendis (Cyprus) and its Wall Paintings, Part I," DOP 44 (1990), 85-86, $92-$ 93, pls 115-116, 120-121, 125-126, 175-178, 181-182.

${ }^{31}$ Djurić, op.cit. (n. 15), 130. See also B. Todić, “The Fresco Painting of the Narthex of Zrze and the Liturgy of Holy Week," Zograf 35 (2011), 211-222.

${ }^{32}$ E. Smirnova, "Obrazmonashestva v russkojzhivopisivtorojpolovini XIV v.," DRI. Sergij Radonezhskij I khudozhestvennajacultura Moskvi XIV-XVvv., Saint-Petersburg 1998, 70-73.

${ }^{33}$ Kollias, op.cit. (n. 9), 12-13.

${ }^{34}$ Antologia khozhdenij russkikh puteshestvennikov. XII-XV veka (ed. E. I. Maleto), Moscow 2005, 228.
} 


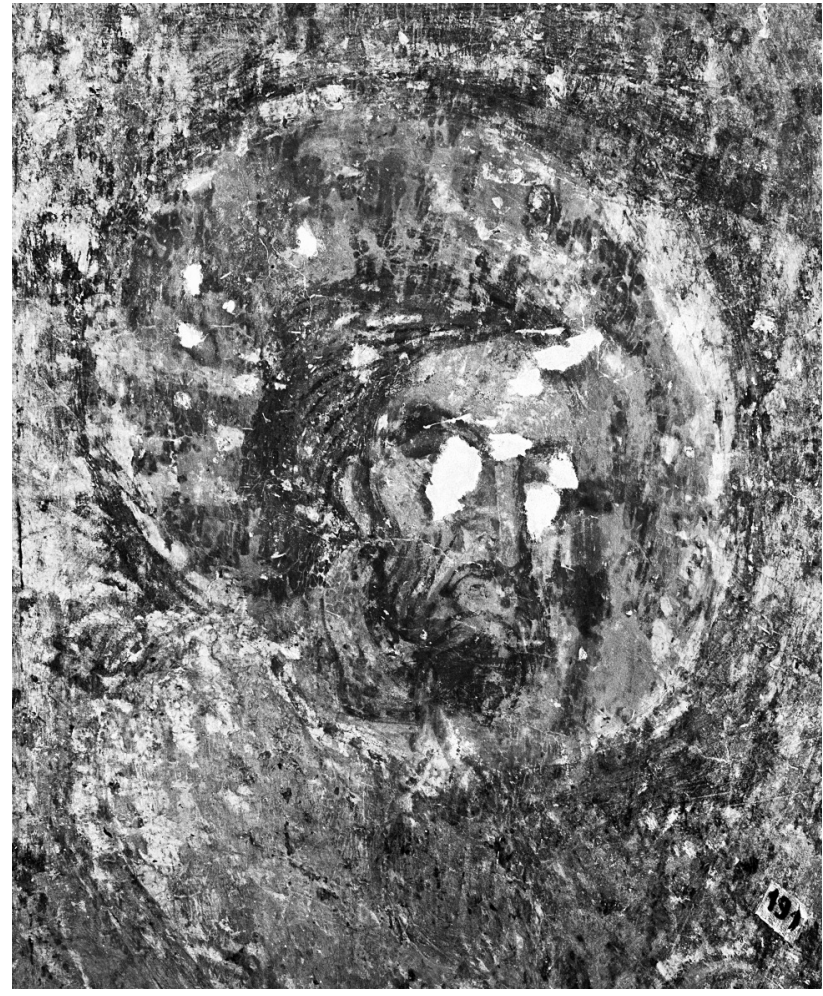

Fig. 20. Polotsk, monastery of Euphrosyna, church of the Savior. Christ and the Samaritan woman. The face of Christ (detail).

These dominant compositions were often set in pairs, which created a juxtaposition between the ideas of death and resurrection. Such an approach, which became very popular in Byzantine art from the 11th century, has long been noted by scholars. ${ }^{35}$ Among monuments of Old Russian art, such an approach is known from the Antoniev (1125) and Mirož (ca. 1140) monasteries, the Boris and Gleb church in Kideksha ( $c a$. 1150), and the Cyril church in Kiev (last quarter of 12th century). The image of the Christ Child who came to suffer and save mankind and of the Virgin on her deathbed gaining resurrection and eternal life through death were usually presented in churches connected with burial rites. In the Savior's church, which was supposed to be the family burial church of Saint Euphrosynia of Polotsk, the scenes with John Chrysostom and Gregory the Theologian emphasize this analogy. Here the streams of water seeming to flow from the side apses and framing the burial arcosolia can actually be understood as springs "of water springing up into everlasting life" (John 4:14).

The study of the Sources of Wisdom compositions in the Savior's church not only demonstrates the iconographical awareness of the artists, but also raises a question of the in-

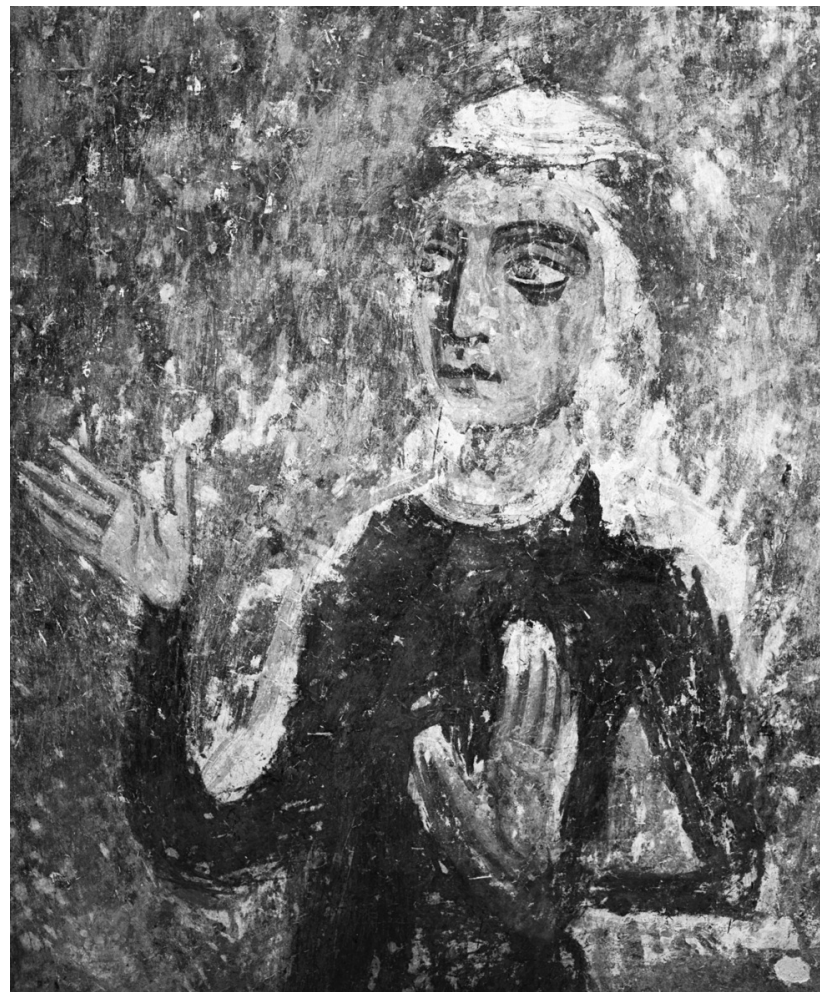

Fig. 21. Polotsk, monastery of Euphrosyna, church of the Savior. Christ and the Samaritan woman. The face of the Samaritan (detail).

teraction between miniatures and murals. Saint Euphosynia of Polotsk must have been using some Byzantine manuscripts she had while working on the iconographic program, which would fully correspond with the spirit of her entire educational activity. The figures of the Evangelists in the pendentives, reminiscent of book miniatures with their complicated iconography, patristic scenes of monastic deeds under the gallery, and episodes from the Lives of bishops in the altar cycle all promote the same thought. But miniatures were not merely examples for the required episodes. The idea of illustration of "the Word" itself shows the enlightening spirit of the whole of Saint Euphrosynia's life and moreover indicates the public mood of that time, when the broad expansion of Christian ideals was so crucial for the Russian Church.

\footnotetext{
${ }^{35}$ H. Maguire, Art and Eloquence in Byzantium, Princeton 1981, 53-68.

Illustration Credits

Figs 1-10, 12-15, 18-21: Vladimir D. Sarabianov. Fig. 11: Walter, Art and Ritual, op.cit. (n. 2), fig. 24. Figs 16, 17: Pelekanidis - Christou Mauropoulou-Tsioumi - Kadas - Katsarou, op.cit. (n. 19), vol. 3, fig. $243,244$.
} 
$\dagger$ Vladimir D. Sarabianov

\section{$\Sigma$ KHNE $\Sigma$ ME THN «ПНГН TH $\Sigma$ ӨEIA $\Sigma \Sigma$ OФIA $\Sigma » \Sigma$ TO

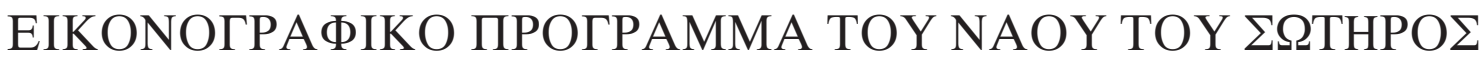 $\Sigma T H$ MONH TH $\Sigma$ AГIA $\Sigma$ EY $\Phi P O \Sigma Y N H \Sigma \Sigma T O$ POLOTSK ( $\Lambda$ EYKOP $\Sigma I A)$}

$\mathrm{M}$

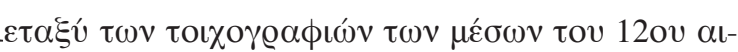

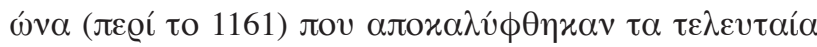

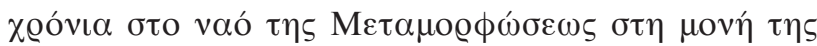

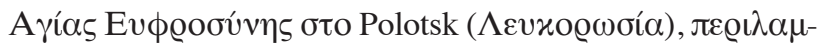

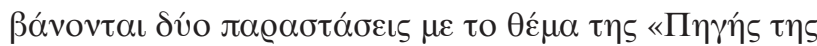

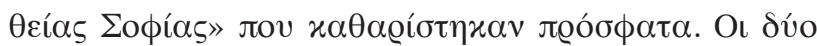

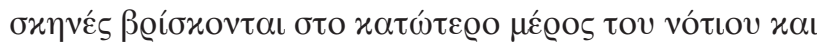

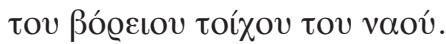

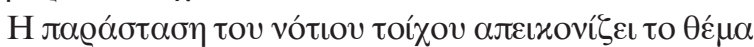

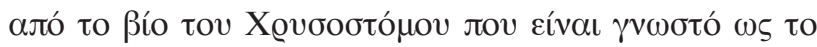

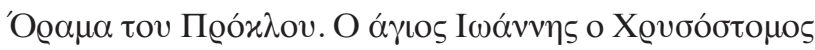

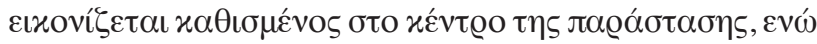

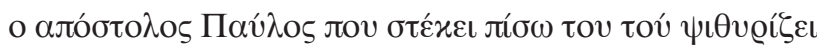

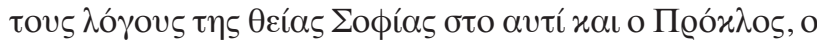

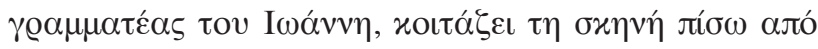

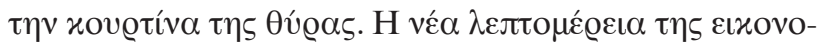

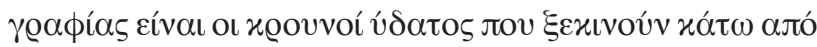

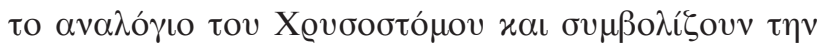

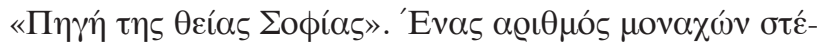

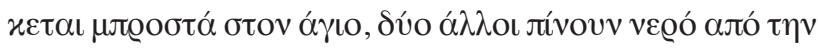

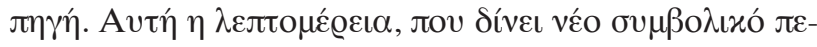

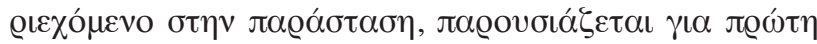

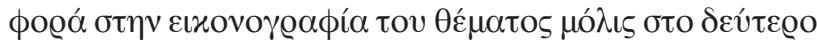

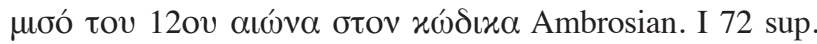

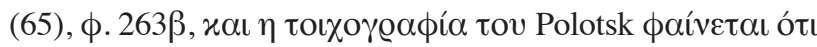

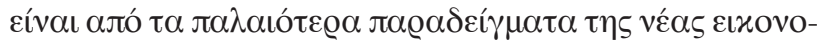

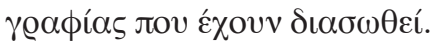

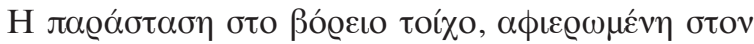

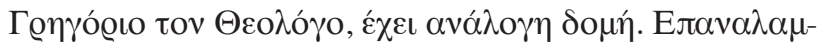

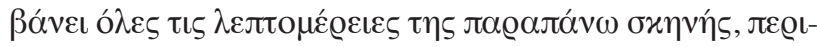

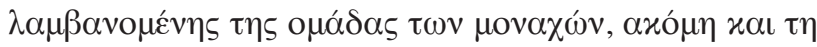

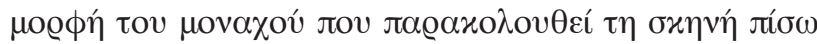

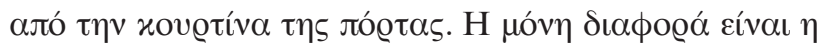

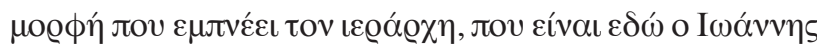

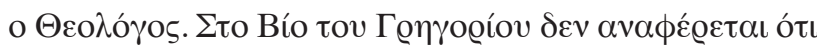

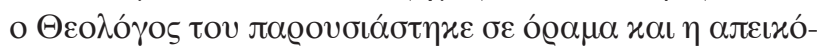

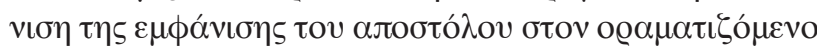

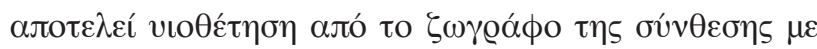

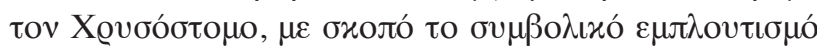

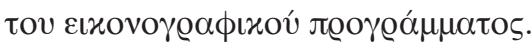

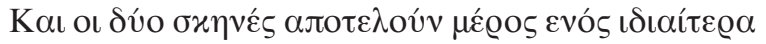

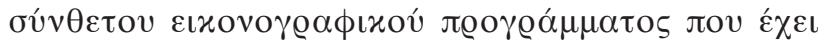

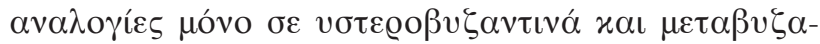

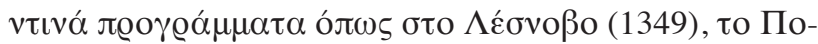

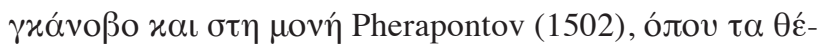

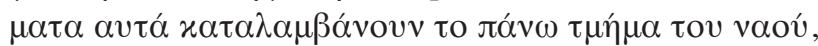

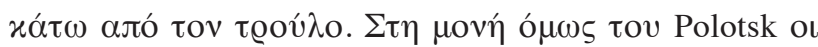

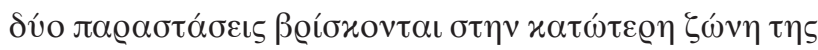

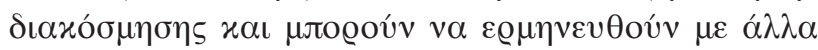

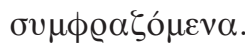

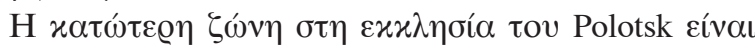

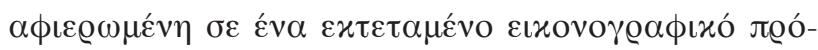

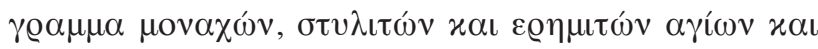

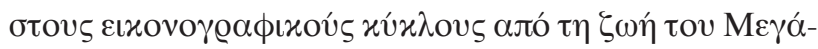

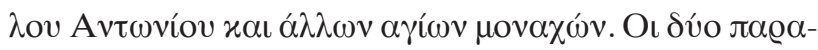

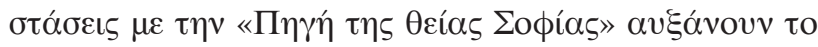

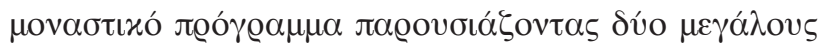

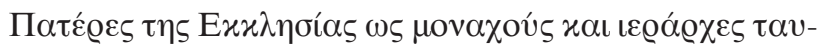

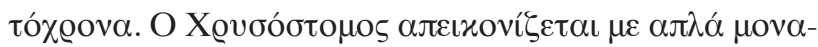

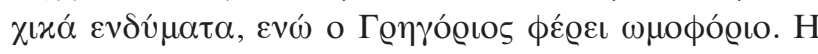

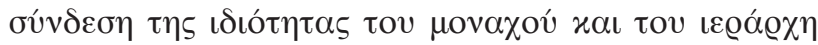

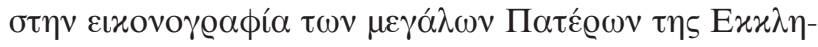

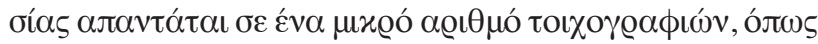

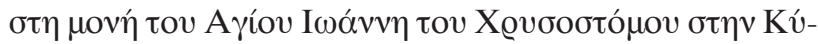

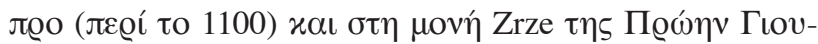

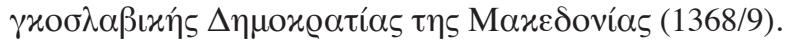

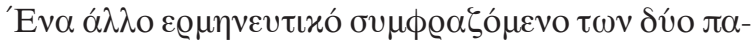

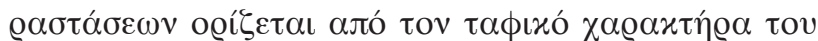

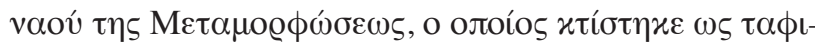

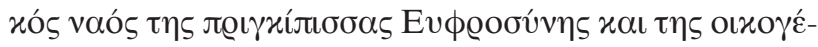

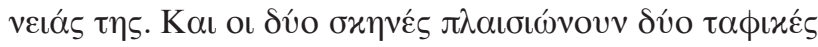

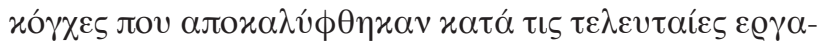

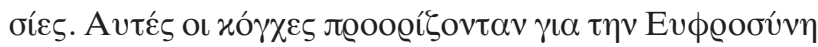

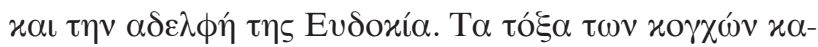

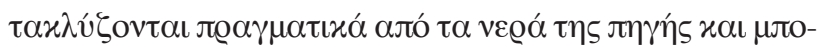

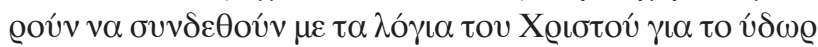

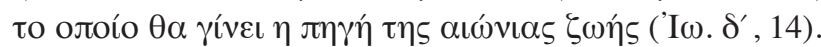

State Institute of Art History, Moscow, vdsar@mail.ru 